Review

\title{
Copeptin and Stress
}

\author{
Marianna Martino and Giorgio Arnaldi *
}

Division of Endocrinology and Metabolic Diseases, Clinical and Molecular Sciences Department (DISCLIMO), Università Politecnica delle Marche, Azienda Ospedaliero-Universitaria "Ospedali Riuniti Ancona", Via Conca 71, 60126 Ancona, Italy; mariannamartino88@gmail.com

* Correspondence: g.arnaldi@staff.univpm.it; Tel.: +39-0715964419

\section{check for} updates

Citation: Martino, M.; Arnaldi, G. Copeptin and Stress. Endocrines 2021, 2,384-404. https://doi.org/ 10.3390/endocrines2040035

Academic Editor: Antonio Brunetti

Received: 2 June 2021

Accepted: 28 September 2021

Published: 12 October 2021

Publisher's Note: MDPI stays neutral with regard to jurisdictional claims in published maps and institutional affiliations.

Copyright: (C) 2021 by the authors. Licensee MDPI, Basel, Switzerland. This article is an open access article distributed under the terms and conditions of the Creative Commons Attribution (CC BY) license (https:// creativecommons.org/licenses/by/ $4.0 /)$.
Abstract: Vasopressin (AVP) and copeptin are released in equimolar amounts from the same precursor. Due to its molecular stability and countless advantages as compared with AVP, copeptin perfectly mirrors AVP presence and has progressively emerged as a reliable marker of vasopressinergic activation in response to osmotic and hemodynamic stimuli in clinical practice. Moreover, evidence highlighting the prognostic potential of copeptin in several acute diseases, where the activation of the AVP system is primarily linked to stress, as well as in psychologically stressful conditions, has progressively emerged. Furthermore, organic stressors induce a rise in copeptin levels which, although non-specific, is unrelated to plasma osmolality but proportional to their magnitude: suggesting disease severity, copeptin proved to be a reliable prognostic biomarker in acute conditions, such as sepsis, early post-surgical period, cardiovascular, cerebrovascular or pulmonary diseases, and even in critical settings. Evidence on this topic will be briefly discussed in this article.

Keywords: vasopressin; copeptin; ACTH; cortisol; HPA axis; stress

\section{Introduction}

Copeptin is the 39-amino acid glycopeptide constituting the C-terminal portion of arginine-vasopressin (AVP) precursor (pro-AVP) [1]; it is produced and released into the bloodstream stoichiometrically with AVP, thus reliably mirroring its presence and activity. Pro-AVP is synthesized in paraventricular and supraoptic magnocellular neuronal nuclei of the hypothalamus [2]. Enzymatic cleavage during axonal transport towards the pituitary gland ensures the formation of the two mature molecules, as well as their split from their carrier, neurophysin II (Figure 1). AVP is then released with copeptin from the posterior pituitary into the systemic circulation in response to hemodynamic and osmotic stimuli, in order to preserve vascular tone (receptors V1a, V1a-R) and fluid homeostasis (V2-R). A second neurosecretory pathway delivers AVP from parvocellular neurons through the portal vessels to the anterior pituitary, where it acts synergistically with corticotropinreleasing hormone $(\mathrm{CRH})$ to stimulate adrenocorticotropic hormone (ACTH) and, thus, cortisol synthesis in response to stressors (V1b-R; Figure 2).

Since its first description in 1972, by Holwerda, as a glycopeptide from the posterior pituitary devoid of any pituitary-related bioactivities but a slight lipolytic effect, copeptin has still unknown functions [3]: it was originally, but inconclusively proposed as the prolactin-releasing factor $[4,5]$, while recently it has been highlighted as a chaperone protein involved in the correct folding and proteolytic maturation of AVP [6,7]. However, copeptin decay kinetics suggests the existence of further specific peripheral activities, even in the absence of identified specific receptors or elimination mechanisms [8]: actually, if its release kinetics in response to hypovolemia, stress and hyperosmolality fully reflects that of AVP [9-12], circulating copeptin half-life reasonably excludes both its accumulation as a junk protein and degradation by circulating proteases in favor of degradation by tissue proteases or hepato-renal clearance [8]. 


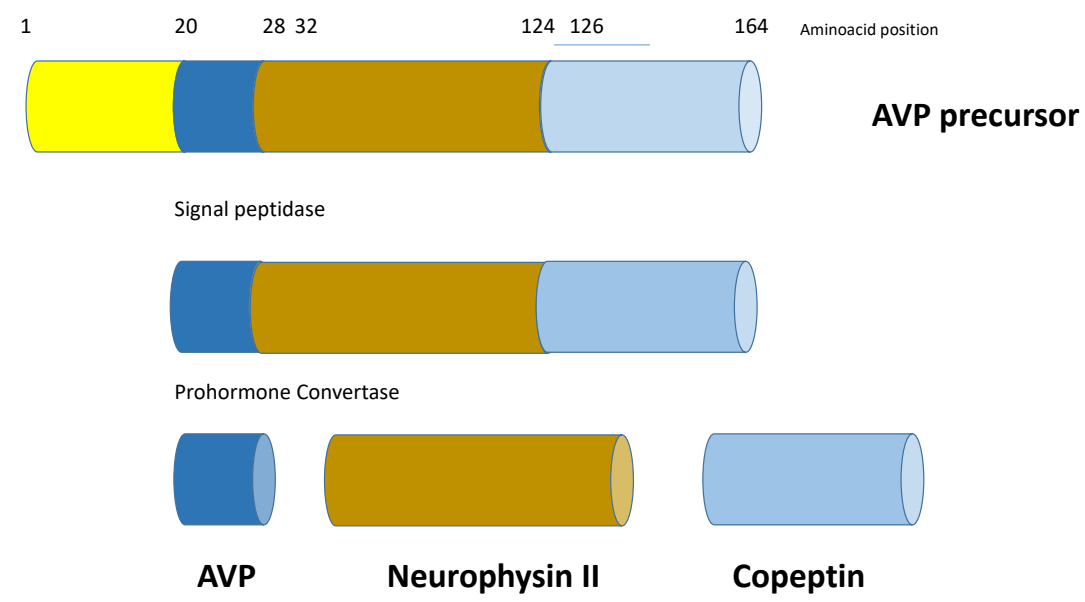

Figure 1. Schematic structure of prepro-vasopressin-neurophysin II-copeptin. Copeptin is the 39-amino acid glycopeptide constituting the C-terminal portion of arginine-vasopressin (AVP) precursor (pro-AVP); it is produced and released into the bloodstream stoichiometrically with AVP. Pro-AVP is synthesized in paraventricular and supraoptic magnocellular neuronal nuclei of the hypothalamus. Enzymatic cleavage during axonal transport towards the pituitary gland ensures the formation of the two mature molecules, as well as their split from their carrier, neurophysin II.

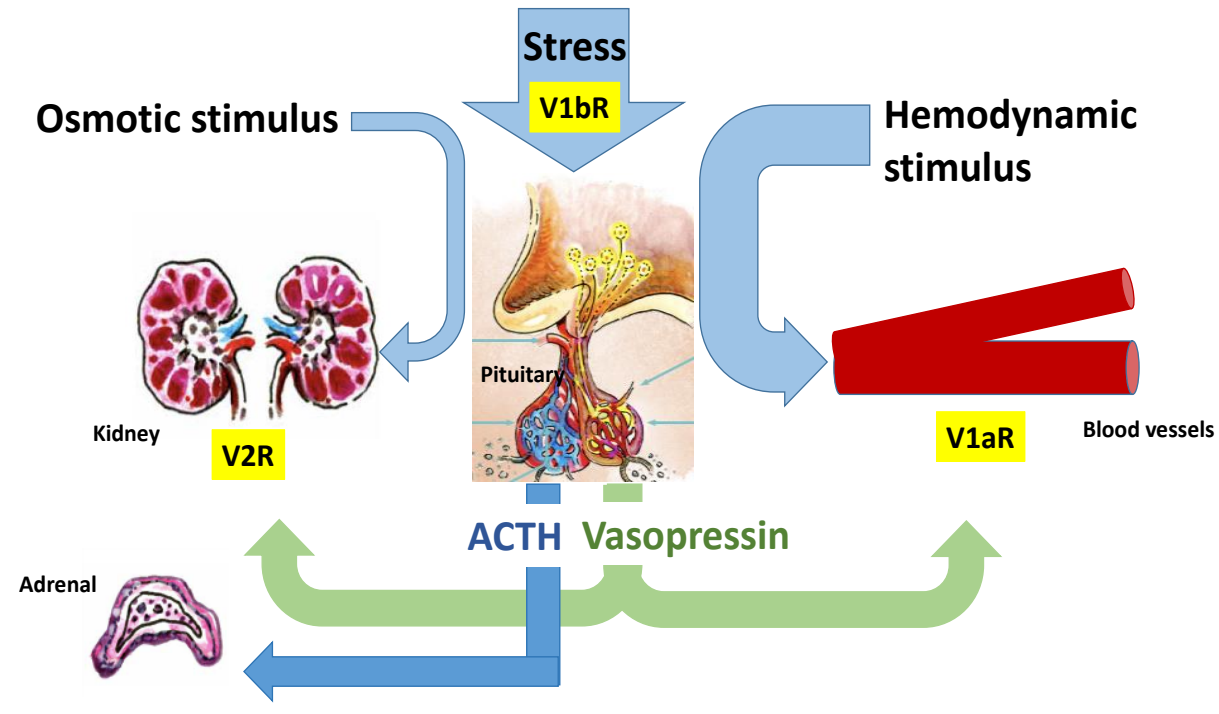

Figure 2. Regulation of arginine vasopressin (AVP) and Copeptin release. AVP is released with copeptin from the posterior pituitary into the systemic circulation in response to hemodynamic and osmotic stimuli, in order to preserve vascular tone (V1a-R) and fluid homeostasis (V2-R). A second neurosecretory pathway delivers AVP from parvocellular neurons through the portal vessels to the anterior pituitary, where it acts synergistically with corticotropin-releasing hormone (CRH) to stimulate adrenocorticotropic hormone (ACTH) and, thus, cortisol synthesis in response to stressors (V1b-R). Moreover, AVP binding to the V1b-R located in the adrenal medulla results in short-term catecholamine secretion.

\section{Stress-Mediated Interaction between AVP System and Hypothalamus-Pituitary-Adrenal (HPA) Axis}

Stress is defined as a state of altered homeostasis, which is triggered by intrinsic or extrinsic adverse factors and associated with complex physiologic and behavioral responses aimed at restoring the optimal body equilibrium.

Circadian cortisol secretion pattern is directly generated by corticotrophs' activity, which is positively regulated by two main factors acting in synergy: CRH and AVP [13]. 
ACTH production increases lately in the night, has a zenith upon awakening and then gradually decreases during the morning. Moreover, a peculiar pulsatility inserts onto this rhythm in response to stress. Countless real or perceived as such, internal or external, organic or psychological stressors can activate both AVP system and HPA axis: among them, the strongest are hypoglycemia, surgical stress, physical exercise, hypotension and acute bleeding, hypoxia and acute diseases with subsequent production of inflammatory cytokines (e.g., interleukin 6, IL-6) [13,14].

By binding pituitary V1b-R, AVP amplifies CRH stimulation on corticotrophs via a two-phase increase in cytosolic calcium resulting in a maximal secretagogue action, which is far more pronounced than the sum of their two separate effects [13]: this redundant, backup mechanism ensures the stress response is properly triggered, being essential both for survival-particularly in conditions of altered glucocorticoid feedback, such as bilateral adrenalectomy or chronic HPA hyperactivation, Cushing's syndrome (CS) and pseudoCushing's states included-and for immunomodulation (the HPA axis regulates the activity of T suppressor lymphocytes) $[15,16]$. Moreover, AVP binding to the V1b-R located in the adrenal medulla and pancreatic islets of Langerhans results in short-term catecholamine secretion and long-term glucose-dependent insulin or glucagon release aimed at enhancing the body performance and preserving energy throughout the stress response [8].

The existence of a close relationship between the AVP system and the HPA axis has been documented by hypothalamic immunoelectron microscopy showing CRH, AVP and copeptin are all co-packaged in neurosecretory vesicles in primates [17] and is also supported by the recent finding of a parallel circadian secretory rhythm for copeptin and cortisol in humans, almost implying-despite the extreme variability of copeptin levels-a pacemaker common to the two hormones or, alternatively, the influence of one on the other, at least in physiological conditions [18]. In healthy subjects copeptin-thus, AVPpeak (h 00-02 a.m.) occurs just before the ACTH zenith and precedes cortisol peak by a few hours; the same pattern is observed when the secretory nadir of the three molecules is reached (h $04-08$ p.m. for copeptin). However, it must be noted that plasma copeptin levels are more stable than those of cortisol and ACTH throughout the day [19]. Further confirmation on this topic is provided by the demonstration of a substantial hypoglycemiainduced copeptin increase following an insulin tolerance test (ITT), both in adults (mean peak $11.1 \mathrm{pmol} / \mathrm{L}$ [20]) and in children and adolescents (mean peak $9.7 \mathrm{pmol} / \mathrm{L}$ [21]) with preserved posterior pituitary function, as well as during a glucagon challenge, where both healthy individuals and subjects with pituitary diseases but preserved anterior function showed a parallel rise in copeptin, ACTH and Growth Hormone (GH), another peptide involved in endocrine stress response [22]. It must be noted that the rise in copeptin levels seems consistent with the pituitary activation in response to ITT, being less marked in case of impaired anterior function [21,23]. Moreover, gender differences were observed, which lead the hypothesized interaction between sex steroids and the AVP system-mediated activation of the HPA axis, at least in adults [23], whereas in children and adolescents copeptin release has been independently associated to prolactin response after ITT [21], thus recalling the long-standing theories on copeptin as the prolactin releasing hormone $[4,5]$.

\section{Is Copeptin a Reliable Stress Biomarker}

Fifty years after the development of the first dedicated radioimmunoassay, a satisfactory routine determination of AVP is still extremely difficult to obtain due to its small dimensions, molecular instability, need for complex preanalytical extraction procedures and is carried out with time-consuming competitive assays of suboptimal diagnostic performance [24,25]. Recently, the development of rapid, highly sensitive immunoassays for copeptin and the availability of such a stable and reliable marker have allowed clinicians to overcome the above-mentioned long-standing issues [26]: with respect to AVP, copeptin measurement takes advantage of lower serum/plasma volumes, no need of preanalytical procedures, optimal analytical performance, promptly available results and a molecular stability of up to 7-14 days in different serum/plasma samples. 
Moreover, the demonstration of a strong correlation between copeptin and AVP levels at different osmolar states $\left(r_{S}=0.8\right)$ and the existence of a more robust correlation between copeptin, rather than AVP, and osmolality $\left(r_{s}=0.77 v s . r_{s}=0.49\right)$ [11] accounts for the assumption that measuring copeptin is equivalent to, or even better than, measuring AVP.

Normal copeptin levels are highly variable [26], slightly higher in males, not influenced by menstrual cycle in females, nor by food ingestion $[27,28]$; as expected, they reduce after water load and increase following physical exercise [26,27]. Correlations with age have not been shown, but copeptin clearance may be distorted as a consequence of the deterioration of kidney function, thus requiring adjustments according to subject's glomerular filtration rate $[26,29]$.

The introduction of copeptin measurement in clinical practice certainly brought important contributions to the management of fluid homeostasis disorders, such as diabetes insipidus and hyponatremia [30]. Similarly, we could hypothesize a role for copeptin in stress conditions, although volemic and osmolar status influence its levels to the extent that stress-specific copeptin cut-offs are still lacking. It must be noticed that osmotic stimulation on copeptin levels is weaker than that provided by hypovolemia/shock or stress/diseases, the former having the strongest impact. Organic stressors induce a rise in copeptin levels which, although non-specific, is unrelated to plasma osmolality but proportional to their magnitude: suggesting disease severity, copeptin proved to be a reliable prognostic biomarker in acute conditions, such as sepsis, early post-surgical period, cardiovascular, cerebrovascular or pulmonary diseases, and even in critical settings (Table 1) [31,32]. Evidence on this topic will be briefly discussed below.

Table 1. Overview of the most important references on copeptin in critically ill patients.

\begin{tabular}{|c|c|c|c|c|}
\hline Article; Year & Number of Patients & Aim & Conclusions & $\begin{array}{c}\text { Prognostic Accuracy } \\
\text { of Copeptin }\end{array}$ \\
\hline \multicolumn{5}{|c|}{ Sepsis and septic shock } \\
\hline Struck et al. [33]; 2005 & $\begin{array}{l}50 \text { healthy controls and } \\
35 \text { patients with } \\
\text { septic shock }\end{array}$ & $\begin{array}{l}\text { To quantify AVP release } \\
\text { by means of a novel } \\
\text { immunometric assay } \\
\text { for copeptin in human } \\
\text { serum and plasma }\end{array}$ & $\begin{array}{l}\text { Plasma levels of } \\
\text { copeptin were strongly } \\
\text { elevated in septic shock } \\
\text { patients as compared } \\
\text { with healthy controls, } \\
\text { but far more stable in } \\
\text { serum and plasma } \\
\text { than AVP. }\end{array}$ & \\
\hline $\begin{array}{l}\text { Morgenthaler et al. [12]; } \\
2007\end{array}$ & 101 critically ill patients & $\begin{array}{l}\text { To test the increase in } \\
\text { copeptin levels in } \\
\text { hemorrhagic and } \\
\text { septic shock }\end{array}$ & $\begin{array}{l}\text { Copeptin levels } \\
\text { increased significantly } \\
\text { with the severity of } \\
\text { disease from infection } \\
\text { without systemic } \\
\text { inflammations to sepsis, } \\
\text { severe sepsis and septic } \\
\text { shock. Copeptin was } \\
\text { higher in non-survivors } \\
\text { than in survivors. }\end{array}$ & $\begin{array}{l}\text { Outcome: in-hospital } \\
\text { mortality } \\
\text { Cut-off } 96 \text { pmol/L } \\
\text { SE 61.5\% SP 83.8\% } \\
\text { AUC 0.75 (95\% CI } \\
0.61-0.86) \\
\text { Multivariate logistic } \\
\text { regression analyses: } \\
\\
\quad \text { with hydration } \\
\text { parameters and } \\
\text { age OR 1.006 (95\% } \\
\text { CI 1.000-1.012) } \\
\quad p=0.04 \\
\text { with stress } \\
\text { parameters OR } \\
1.007 \text { (95\% CI } \\
1.001-1.013) \\
p=0.03\end{array}$ \\
\hline
\end{tabular}


Table 1. Cont.

\begin{tabular}{|c|c|c|c|c|}
\hline Article; Year & Number of Patients & Aim & Conclusions & $\begin{array}{c}\text { Prognostic Accuracy } \\
\text { of Copeptin }\end{array}$ \\
\hline $\begin{array}{l}\text { Jochberger et al. [34]; } \\
2009\end{array}$ & $\begin{array}{l}10 \text { patients with } \\
\text { infection, } 22 \text { with } \\
\text { severe sepsis and } \\
28 \text { with septic shock }\end{array}$ & $\begin{array}{l}\text { To compare the course } \\
\text { of AVP and copeptin } \\
\text { plasma concentrations } \\
\text { between patients with } \\
\text { infection, severe sepsis, } \\
\text { and septic shock }\end{array}$ & $\begin{array}{l}\text { Severe sepsis induced a } \\
\text { stronger AVP response } \\
\text { than infection without } \\
\text { systemic inflammation. } \\
\text { The lack of a difference } \\
\text { in AVP plasma } \\
\text { concentrations between } \\
\text { patients with and } \\
\text { without shock indicates } \\
\text { that the AVP system } \\
\text { does not function } \\
\text { normally in } \\
\text { severe sepsis. }\end{array}$ & \\
\hline Zhang et al. [35]; 2014 & $\begin{array}{l}461 \text { patients referring to } \\
\text { the emergency } \\
\text { department with } \\
\text { symptoms of systemic } \\
\text { inflammatory response } \\
\text { syndrome (SIRS) }\end{array}$ & $\begin{array}{l}\text { To assess the } \\
\text { predictive value of } \\
\text { copeptin } \\
\text { in determining sepsis } \\
\text { progression and } \\
\text { mortality in the } \\
\text { emergency department }\end{array}$ & $\begin{array}{l}\text { Increased copeptin at } \\
\text { admission may provide } \\
\text { crucial information for } \\
\text { risk stratification in the } \\
\text { different stages of } \\
\text { sepsis. Copeptin is an } \\
\text { independent prognostic } \\
\text { biomarker for mortality } \\
\text { in patients with severe } \\
\text { sepsis or septic shock. }\end{array}$ & $\begin{array}{l}\text { Outcome: septic shock } \\
\text { Cut-off } 96.5 \text { pmol/L } \\
\text { SE } 78.9 \% \text { SP } 87.1 \% \\
\text { AUC 0.856 (95\% CI } \\
0.814-0.897) \\
\text { OR 1.034 }(95 \% \text { CI } \\
1.023-1.044) p<0.001 \\
\text { Outcome: } 28-\text { day } \\
\text { mortality } \\
\text { Cut-off } 86.3 \text { pmol/L } \\
\text { SE } 85.3 \% \text { SP } 59.8 \% \\
\text { AUC 0.826 (95\% CI } \\
0.780-0.871) \\
\text { OR 1.039 (95\% CI } \\
1.026-1.051) p<0.001\end{array}$ \\
\hline Mazzeo et al. [36]; 2019 & $\begin{array}{l}11 \text { critically ill patients } \\
\text { admitted in ICU }\end{array}$ & $\begin{array}{l}\text { To investigate the early } \\
\text { activation of pituitary } \\
\text { axes in response } \\
\text { to stress. }\end{array}$ & $\begin{array}{l}\text { Copeptin elevation was } \\
\text { common and persistent } \\
\text { in critical illnesses. Its } \\
\text { magnitude changed } \\
\text { according to the } \\
\text { underlying condition } \\
\text { (ARDS > TBI > SAH), } \\
\text { but copeptin levels did } \\
\text { not predict } \\
\text { in-hospital mortality. }\end{array}$ & \\
\hline $\begin{array}{l}\text { Zampino et al. [37]; } \\
2021\end{array}$ & $\begin{array}{l}196 \text { patients with } \\
\text { infective endocarditis }\end{array}$ & $\begin{array}{l}\text { To assess the prognostic } \\
\text { role for copeptin and } \\
\text { other biomarkers in } \\
\text { infective endocarditis }\end{array}$ & $\begin{array}{l}\text { Different biomarkers } \\
\text { correlate with distinct } \\
\text { outcomes in infective } \\
\text { endocarditis. Copeptin } \\
\text { may signal a worse } \\
\text { prognosis and could be } \\
\text { used to identify } \\
\text { patients who need } \\
\text { more aggressive } \\
\text { treatment; it does not } \\
\text { provide information on } \\
\text { embolic risk or etiology. }\end{array}$ & $\begin{array}{l}\text { Outcome: in-hospital } \\
\text { mortality } \\
\text { AUC } 0.731 \\
\text { Outcome: 1-year } \\
\text { mortality } \\
\text { OR } 2.55 \text { (95\% CI } \\
1.18-5.54) p=0.017\end{array}$ \\
\hline
\end{tabular}


Table 1. Cont.

\begin{tabular}{|c|c|c|c|}
\hline Article; Year & Number of Patients & Aim & Conclusions \\
\hline & \multicolumn{3}{|c|}{ Traumatic brain injury (TBI) } \\
\hline Dong et al. [38]; 2011 & $\begin{array}{l}94 \text { patients with acute } \\
\text { severe TBI and } \\
50 \text { healthy controls }\end{array}$ & $\begin{array}{l}\text { To evaluate the } \\
\text { relationship between } \\
\text { copeptin levels and } \\
\text { mortality after TBI }\end{array}$ & $\begin{array}{l}\text { Copeptin levels were } \\
\text { significantly higher in } \\
\text { patients with TBI than } \\
\text { in healthy controls. } \\
\text { Among TBI patients, } \\
\text { copeptin levels } \\
\text { correlated inversely } \\
\text { with GCS and were } \\
\text { significantly higher in } \\
\text { non-survivors after } \\
1 \text { month. }\end{array}$ \\
\hline
\end{tabular}

Prognostic Accuracy of Copeptin

\begin{tabular}{|c|c|c|c|c|}
\hline Zhang et al. [39]; 2021 & $\begin{array}{l}2654 \text { patients from } \\
17 \text { studies } \\
\text { (meta-analysis) on TBI }\end{array}$ & $\begin{array}{l}\text { To assess the diagnostic } \\
\text { and prognostic value of } \\
\text { plasma copeptin } \\
\text { after TBI }\end{array}$ & $\begin{array}{l}\text { Copeptin is a } \\
\text { promising biomarker in } \\
\text { the diagnosis and } \\
\text { prognosis of TBI } \\
\text { patients in terms of } \\
\text { complications, } \\
\text { mortality, poor } \\
\text { functional outcome. }\end{array}$ & $\begin{array}{l}\text { Outcome: brain } \\
\text { concussion } \\
\text { AUC 0.90 (95\% CI } \\
0.84-0.95) \\
\text { Outcome: progressive } \\
\text { hemorrhagic injury } \\
\text { AUC 0.83 (95\% CI } \\
\text { 0.80-0.87) } \\
\text { Outcome: acute } \\
\text { traumatic coagulopathy } \\
\text { AUC 0.84 (95\% CI } \\
\text { 0.79-0.89) } \\
\text { Outcome: mortality } \\
\text { AUC 0.89 (0.87-0.92) } \\
\text { Outcome: poor } \\
\text { functional outcomes } \\
\text { AUC 0.88 (95\% CI } \\
0.84-0.92)\end{array}$ \\
\hline
\end{tabular}

303 patients with an initial diagnosis of aneurysmal SAH
To investigate the ability of copeptin to predict disease outcome and brain vasospasm in patients with SAH.
Outcome: 1-month mortality

Cut-off $112 \mathrm{pmol} / \mathrm{L}$ SE $88.5 \%$ SP $75 \%$ AUC $0.874(95 \%$ CI

0.789-0.933)

OR 1.008 (95\% CI

$1.002-1.014) p=0.010$

Outcome: brain concussion

(95\% CI AUC 0.83 (95\% CI AUC 0.84 (95\% CI AUC 0.88 (95\% CI

Outcome: in-hospital mortality Cut-off 28.7 pmol/L SE $78.1 \%$ SP $89.7 \%$ AUC $0.868 \pm 0.042$ Outcome: 1-year mortality Cut-off $20.5 \mathrm{pmol} / \mathrm{L}$ SE $92.8 \%$ SP $70.1 \%$

AUC $0.868 \pm 0.036$

OR 2.307 (95\% CI 1.324-6.974) $p=0.004$

Outcome: 1-year poor functional outcome Cut-off $23.8 \mathrm{pmol} / \mathrm{L}$ SE $82.2 \%$ SP $79.8 \%$ AUC $0.860 \pm 0.026$

Outcome: cerebrovasospasm Cut-off $23.4 \mathrm{pmol} / \mathrm{L}$ SE $69.2 \%$ SP $84.9 \%$ AUC $0.792 \pm 0.027$ 
Table 1. Cont

\begin{tabular}{clll}
\hline Article; Year & Number of Patients & \multicolumn{1}{c}{ Aim } & \multicolumn{1}{c}{ Conclusions } \\
\hline Fung et al. [41]; 2013 & $\begin{array}{l}\text { 18 patients with } \\
\text { aneurysmal SAH }\end{array}$ & $\begin{array}{l}\text { To investigate the } \\
\text { association between } \\
\text { copeptin levels and the } \\
\text { severity and prognosis } \\
\text { of SAH. }\end{array}$ & $\begin{array}{l}\text { Copeptin levels may } \\
\text { indicate clinical } \\
\text { severity of the initial } \\
\text { bleeding, thus being } \\
\text { helpful in guiding } \\
\text { treatment decisions. }\end{array}$ \\
\hline
\end{tabular}

Zuo et al. [42]; 2019

243 patients with aneurysmal SAH
To investigate the prognostic value of copeptin in patients with $\mathrm{SAH}$
Copeptin is a promising biomarker in predicting short-term functional outcomes and mortality in SAH.
Prognostic Accuracy of Copeptin

Outcome: 3-month poor functional outcome

Cut-off $24 \mathrm{pmol} / \mathrm{L}$ SE $70.5 \%$ SP $69.6 \%$ AUC 0.74 (95\% CI 0.67-0.81)

OR $1.06(95 \% \mathrm{CI}$

$1.02-1.10) p<0.001$

Outcome: 3-month mortality

AUC 0.81 (95\% CI

0.74-0.87)

OR $1.09(95 \% \mathrm{CI}$

$0.74-0.87) p<0.001$

Cut-off $31.2 \mathrm{pmol} / \mathrm{L}$

OR 4.13 (95\% CI

1.75-7.12)

Copeptin is one of the

15 non-genetic predictors of delayed cerebral ischemia after SAH with a level of evidence II.
To assess the predictive value of 257 biomarkers for delayed cerebral ischemia after $\mathrm{SAH}$
16914 patients from (systematic review) on $\mathrm{SAH}$
To evaluate the prognostic power of copeptin in predicting delayed cerebral ischemia after $\mathrm{SAH}$
If associated with transcranial doppler ultrasound, copeptin levels are of additive value in predicting the occurrence of delayed cerebral ischemia after SAH.
Outcome: delayed cerebral ischemia OR $1.022(95 \%$ CI 1.008-1.037) $p=0.002$ Performance of transcranial doppler: AUC 0.667 (95\% CI 0.548-0.771)

Performance of Copeptin with transcranial doppler: AUC $0.739(95 \%$ CI 0.625-0.834)

Intracerebral hemorrhage (ICH)

To investigate changes

\section{in plasma}

copeptin levels in patients during the

86 patients with acute

Dong et al. [45]; 2011

\section{$\mathrm{ICH}$ and}

30 healthy controls initial 7-day period after $\mathrm{ICH}$ and also determine whether copeptin is an independent prognostic marker of mortality in $\mathrm{ICH}$
Increased plasma copeptin is associated with hematoma volume and is an independent prognostic biomarker of mortality after ICH.
Outcome: 1-week mortality Cut-off 143.7 pmol/L SE $87.5 \%$ SP $72.2 \%$ AUC 0.873 (95\% CI 0.784-0.935)

OR $1.013(95 \%$ CI $1.003-1.023) p=0.009$ 
Table 1. Cont.

\begin{tabular}{|c|c|c|c|c|}
\hline Article; Year & Number of Patients & Aim & Conclusions & $\begin{array}{c}\text { Prognostic Accuracy of } \\
\text { Copeptin }\end{array}$ \\
\hline Zhang et al. [46]; 2012 & $\begin{array}{l}89 \text { patients with acute } \\
\text { spontaneous basal ganglia } \\
\text { hemorrhage and } \\
50 \text { healthy controls }\end{array}$ & $\begin{array}{l}\text { To evaluate the } \\
\text { relationship between } \\
\text { plasma copeptin levels } \\
\text { and both long-term } \\
\text { outcome and early } \\
\text { neurological deterioration } \\
\text { after ICH }\end{array}$ & $\begin{array}{l}\text { Increased plasma copeptin } \\
\text { is an independent } \\
\text { prognostic marker of } \\
\text { 1-year mortality, 1-year } \\
\text { unfavorable outcome } \\
\text { and early } \\
\text { neurological deterioration } \\
\text { after ICH. }\end{array}$ & $\begin{array}{l}\text { Outcome: } 1 \text {-year mortality } \\
\text { OR 1.138 }(95 \% \text { CI } \\
\text { 1.063-1.345) } p<0.001 \\
\text { Outcome: } 1 \text {-year poor } \\
\text { functional outcome } \\
\text { OR 1.191 }(95 \% \text { CI } \\
\text { 1.102-1.323) } p<0.001 \\
\text { Outcome: early } \\
\text { neurological deterioration } \\
\text { OR 1.217 (95\% CI } \\
1.139-1.398) p<0.001\end{array}$ \\
\hline Zhang et al. [47]; 2013 & $\begin{array}{l}120 \text { patients with } \\
\text { acute ICH }\end{array}$ & $\begin{array}{l}\text { To examine the prognostic } \\
\text { value of copeptin in } \\
\text { acute ICH }\end{array}$ & $\begin{array}{l}\text { Copeptin is correlated } \\
\text { with clinical, biochemical } \\
\text { and radiologic parameters } \\
\text { of ICH severity. Copeptin } \\
\text { levels are independent } \\
\text { predictors of 90-day } \\
\text { functional outcome in } \\
\text { ICH patients. }\end{array}$ & $\begin{array}{l}\text { Outcome: impaired } \\
\text { nerve function } \\
\text { OR } 3.17 \text { ( } 95 \% \text { CI } 2.01-4.35) \\
p=0.003 \\
\text { Outcome: cerebral } \\
\text { hemorrhage } \\
\text { OR } 1.28 \text { (95\% CI 1.05-1.48) } \\
p<0.001 \\
\text { Outcome: } 90 \text {-day } \\
\text { mortality } \\
\text { OR } 5.29 \text { (95\% CI 3.68-8.03) } \\
p<0.001\end{array}$ \\
\hline
\end{tabular}

Vasodilatory shock/post-surgical vasoplegia

\begin{tabular}{|c|c|c|c|c|}
\hline Colson et al. [48]; 2011 & $\begin{array}{l}64 \text { consecutive patients } \\
\text { undergoing elective } \\
\text { cardiopulmonary } \\
\text { bypass surgery }\end{array}$ & $\begin{array}{l}\text { To assess the prognostic } \\
\text { value of preoperative } \\
\text { copeptin levels for } \\
\text { cardiovascular instability } \\
\text { in the immediate } \\
\text { post-surgical period }\end{array}$ & $\begin{array}{l}\text { High preoperative } \\
\text { copeptin levels are } \\
\text { predictive of post cardiac } \\
\text { surgery vasodilation and } \\
\text { suggestive of the AVP } \\
\text { system activation which } \\
\text { predisposes patients to a } \\
\text { relative AVP deficiency } \\
\text { after surgical stress. }\end{array}$ & $\begin{array}{l}\text { Outcome: } \\
\text { post-cardiotomic } \\
\text { vasoplegia } \\
\text { Cut-off } 9.43 \mathrm{pmol} / \mathrm{L} \\
\text { SE } 90 \% \text { SP } 77 \% \\
\text { AUC } 0.86 \pm 0.04(95 \% \text { CI } \\
0.78-0.94)\end{array}$ \\
\hline Braun et al. [49]; 2019 & & $\begin{array}{l}\text { To evaluate the prognostic } \\
\text { value of copeptin levels } \\
\text { for the early development } \\
\text { of organ failure in patients } \\
\text { undergoing allogeneic } \\
\text { hematopoietic cell } \\
\text { transplantation }\end{array}$ & $\begin{array}{l}\text { Serial copeptin } \\
\text { measurements improve } \\
\text { the risk prediction for ICU } \\
\text { admission for need for } \\
\text { organ support as } \\
\text { calculated by the } \\
\text { continuous net } \\
\text { reclassification } \\
\text { improvement in allogeneic } \\
\text { hematopoietic stem } \\
\text { transplantation recipients. }\end{array}$ & $\begin{array}{l}\text { Outcome: need for } \\
\text { organ support } \\
\text { Cut-off: } 13.8 \text { pmol/L } \\
\text { SE } 83 \% \text { SP } 71 \% \\
\text { AUC } 0.820\end{array}$ \\
\hline Pasero et al. [50]; 2020 & $\begin{array}{l}350 \text { consecutive patients } \\
\text { undergoing on-pump } \\
\text { cardiac surgery }\end{array}$ & $\begin{array}{l}\text { To assess the prognostic } \\
\text { value of perioperative } \\
\text { HPA axis parameters and } \\
\text { copeptin levels for } \\
\text { cardiovascular instability } \\
\text { in the immediate } \\
\text { post-surgical period }\end{array}$ & $\begin{array}{l}\text { Higher preoperative } \\
\text { copeptin levels, but not a } \\
\text { reduced response to } \\
\text { ACTH stimulation, are } \\
\text { predictive for } \\
\text { post-cardiotomic } \\
\text { vasoplegia. }\end{array}$ & $\begin{array}{l}\text { Outcome: } \\
\text { post-cardiotomic } \\
\text { vasoplegia } \\
\text { Cut-off } 16.9 \mathrm{pmol} / \mathrm{L} \\
\text { SE } 89 \% \text { SP } 86 \% \\
\text { AUC } 0.86(95 \% \text { CI } \\
0.73-0.94) \\
\text { OR } 1.17 \text { (95\% CI 1.04-1.32) }\end{array}$ \\
\hline
\end{tabular}

\subsection{Sepsis and Septic Shock}

It has long been known that in the early phase of septic shock AVP levels rise, but a similar trend has been observed also for copeptin, which in intensive care settings was demonstrated to be an independent predictor for the development of septic shock on one hand and, on the other, a reliable biomarker of disease presence $(375 \mathrm{pmol} / \mathrm{L}$ in septic shock vs. $0.88 \mathrm{pmol} / \mathrm{L}$ in healthy controls [33]) and progression from systemic inflammatory response syndrome (SIRS) to sepsis, severe sepsis and septic shock [12,35]. In a cohort of 101 patients with septic shock, indeed, copeptin levels were more than 30- and 6-fold 
higher than in healthy individuals and patients with SIRS, respectively [12]; in the same cohort, copeptin levels at hospital admission for septic shock were the only outcome predictor, being significantly higher in non-survivors than in survivors (171.5 vs. $86.8 \mathrm{pmol} / \mathrm{L}$ ). Also, copeptin levels at hospital admission for acute infective endocarditis independently predicted longer-term mortality (OR 2.55 for 1-year mortality) [37]. Conversely, hypovolemia is the main stimulus for AVP release in hemorrhagic shock, accounting for a 36 -fold increase in copeptin levels which, however, reverted only partially one hour after reperfusion in an experimental baboon model, consistently with the ongoing stress response $(7.5 \rightarrow 269 \rightarrow 24 \mathrm{pmol} / \mathrm{L})[12]$.

\subsection{Critical Illness and Intensive Care Setting}

Outdated, prospective data on a large cohort $(n=157)$ showed that, if assessed $24 \mathrm{~h}$ after admission in intensive care units (ICU), whether for critical illness or after cardiac surgery, AVP and copeptin levels were significantly higher than those found in healthy subjects (87 vs. 6 pmol/L) [34].

A recent post-hoc analysis conducted on 113 critically ill patients admitted in ICU, aimed at investigating the early activation of pituitary axes in response to stress, demonstrated an elevation in copeptin levels in $68 \%$ of patients, whose magnitude was different according to the underlying critical illness [36]: alterations in copeptin were more common $(97 \%)$ and severe (50-60 pmol/L) in patients with acute respiratory distress syndrome (ARDS), whereas in patients with traumatic brain injury (TBI) and subarachnoid hemorrhage (SAH) they had lower prevalence (63 and $86 \%$, respectively) and entity (20-30 and 10-20 pmol/L, respectively). Copeptin elevation was persistent from day 1 to 5 in all groups, but it did not result as a predictor of ICU mortality. Notably, patients with neurologic illness at the moment of brain death had no AVP system activation, further empowering the potential for copeptin as a biomarker of stress response.

Perioperative copeptin assessment is useful to evaluate the risk of ICU admission in the immediate post-surgical period for cardiovascular instability: in particular, higher copeptin levels before cardiopulmonary bypass and 3 days after allogeneic hematopoietic cell transplantation were found to predict accurately the development of post-cardiotomic vasoplegia ( $\mathrm{AUC}=0.860$ in different cohorts) and overt clinical deterioration requiring organ support (AUC $=0.820$ ), respectively [48-50]. Also, some of the latest observational and intervention studies depicted copeptin as a predictor of organ failure, death in ICU (along with cortisol), 30-day mortality, circulatory cause of death and long-term neurological outcomes after out-of-hospital cardiac arrest [51-53].

Copeptin has been proposed as a diagnostic biomarker of acute pulmonary embolism (APE) [54]: in a prospective study on 90 patients consecutively referring to the emergency department for acute chest pain and/or dyspnea copeptin was found to be significantly increased in those with radiologically confirmed APE (7.76 vs. $3.81 \mathrm{ng} / \mathrm{dL} ; p<0.001)$, resulting an independent predictor of APE after adjusted multivariate analysis (OR 1.836, $95 \%$ CI 1.171-2.878, $p=0.008$ ). Also, copeptin levels were inversely correlated both with oxygen saturation and echocardiographic indexes of right ventricle dilatation and pulmonary hypertension, the latter pointing out a role for copeptin as a prognostic biomarker of obstructive cardiogenic shock in APE. Several studies on large cohorts support this assumption by showing copeptin measurement could help stratifying the short-term risk of death after APE [55-58]. Wyzgał et al. found significantly higher median copeptin levels in non-survivors than in survivors ( $84.6 \mathrm{vs} .18 .7 \mathrm{pmol} / \mathrm{L}, n=107)$, as well as in patients with complicated than with benign clinical course (53.1 vs. $18.2 \mathrm{pmol} / \mathrm{L}$ ), the former being predicted by copeptin levels $\geq 18.0 \mathrm{pmol} / \mathrm{L}$ (AUC 0.811) [55]. Previously, Hellenkamp et al. had obtained similar results in a prospective evaluation of 268 normotensive APE patients, demonstrating that those with an adverse 30-day outcome had higher median copeptin levels than those with a benign 30-day outcome (51.8 vs. $13.2 \mathrm{pmol} / \mathrm{L}$ ) and that copeptin levels $\geq 24 \mathrm{pmol} / \mathrm{L}$ were associated to a 5.4 -fold increased risk for adverse outcome in a stepwise biomarker-based risk assessment strategy [56]; the following multicentric val- 
idation study conducted on 843 normotensive APE patients confirmed copeptin levels $\geq 24 \mathrm{pmol} / \mathrm{L}$ determined a 6.3- and 7.6-fold increased risk for adverse 30-day outcome and APE-related death, respectively; moreover, when added to the standard algorithm, copeptin was found to improve risk stratification in increased-risk patients (OR 11.1 and 13.5 for adverse outcome and APE-related death, respectively) [57].

\subsection{Pulmonary Diseases}

A marked increase in copeptin levels has been documented in large cohorts of patients with lower respiratory tract infections ( $25.3 \mathrm{vs.} 5.0 \mathrm{pmol} / \mathrm{L}$ of healthy controls, $p<0.001$ ), especially Community-Acquired Pneumonia (CAP) [59]. In this condition, correlations were repeatedly shown between copeptin and clinical indexes of pneumonia severity, such as Pneumonia Severity Index (PSI) or CURB score [59-61], so that copeptin has become a useful, complementary tool for the risk stratification of patients with CAP [62]. Moreover, several studies on large cohorts of patients with CAP reported significantly higher copeptin levels at hospital admission in non-survivors than in survivors (70.0 vs. $24.3 \mathrm{pmol} / \mathrm{L}, n=343$ [49]; 44.2 vs. $12.4 \mathrm{pmol} / \mathrm{L}, n=589$ [60]; 24.9 vs. $8.1 \mathrm{pmol} / \mathrm{L}$, $n=173$ [61]), also showing that copeptin could predict mortality (non-survivors vs. survivors: 42.6 vs. $11.2 \mathrm{pmol} / \mathrm{L}$ for 28 -day mortality and $33.2 \mathrm{vs}$. $10.7 \mathrm{pmol} / \mathrm{L}$ for 180-day mortality, $n=1740$ [63]) with higher accuracy than both biochemical indexes, such as C Reactive Protein (CRP) or procalcitonin, and clinical risk scores, such as PSI, CURB and CRB-65 scores, which are currently used only for research purposes [63,64].

Similarly, in 167 patients admitted to the emergency department for acute exacerbations of Chronic obstructive pulmonary disease (COPD) and re-evaluated 14 days and 6 months after, higher copeptin levels at hospital admission were found to be a reliable prognostic biomarker of in-hospital and long-term outcome, being associated with prolonged hospitalization and long-term clinical failure $(p<0.0001$ at a cut-off value of $40 \mathrm{pmol} / \mathrm{L}$ ) regardless of age, patients' comorbidities, hypoxia level and degree of functional lung impairment [65].

Although similar between children in remission and with acute exacerbations of cystic fibrosis, higher copeptin levels were correlated with symptoms severity and radiological changes $(\mathrm{r}=-0.77 p=0.008$ and $\mathrm{r}=-0.56 p=0.036$, respectively) as expressed by the Shwachman-Kulczycki and the Brasfield scores in the latter [66].

Latest evidence suggests copeptin could be a promising biomarker in distinguishing the novel oronavirus disease-19 (COVID-19) pneumonia from CAP, albeit with substantial limitations [67]: in a small cohort of non-critical patients, indeed, copeptin levels were found to be higher in COVID-19 pneumonia than in CAP $(10.2$ vs. $7.1 \mathrm{ng} / \mathrm{mL}, p<0.001)$, being also the best independent predictor of COVID-19 pneumonia (OR 1.183 95\% CI $1.033-1.354 p=0.015$ ) with reasonable accuracy at a cut-off of $6.83 \mathrm{ng} / \mathrm{mL}$ (AUC 0.764).

Copeptin behavior in obstructive sleep apnea (OSA) is debated: since hypoxia is a potent stimulus for AVP secretion, most authors state copeptin is a useful diagnostic marker in OSA, supported by the findings of significantly higher plasma levels in patients than in controls, both at OSA diagnosis and after 6 or 12 months of continuous positive airway pressure (C-PAP) therapy in large cohorts [68-70]. However, evidence concerning the prognostic role of copeptin in OSA is controversial: Cinarka et al. $(n=116)$ observed significant correlations between copeptin levels and severity of OSA according to polysomnographic indexes and inflammation biomarkers [69], but their results were not confirmed by neither contemporary (Selçuk et al., $n=47$ ) nor more recent studies, with even larger cohorts (Karakioulaki et al., $n=232$ ) [68,71].

\subsection{Heart Failure and Acute Myocardial Infarction}

Heart failure (HF) is characterized by elevated copeptin levels, which are inappropriate to the common findings of hyponatremia and reduced plasma osmolality [72]. This is not surprising, since the activation of AVP system in edematous conditions is primarily driven by non-osmotic factors (intra-cardiac and intra-arterial pressures, angiotensin II, 
pain, adrenergic stimulation on central nervous system), rather than physiological osmotic mechanisms [73]. In turn, copeptin could represent a biomarker of disease severity: indeed, AVP action on both V1-R and V2-R contributes to the progression of left ventricular dysfunction by stimulating myocardial remodeling and altering preload, filling pressures and afterload [72,73].

Whether alone or in association with the gold standard biomarker brain natriuretic peptide (BNP), higher copeptin levels have been associated to poor short- and long-term clinical and therapeutic outcomes, as well as all-cause mortality in patients with HF [74,75].

Specifically, copeptin was shown to be superior to BNP in predicting 3-month death or re-hospitalization and comparable to BNP in predicting 12-month all-cause mortality in 155 (survivors vs. non-survivors/re-hospitalized: 25 vs. $42 \mathrm{pmol} / \mathrm{L}$ ) and 137 (survivors vs. non-survivors: 21 vs. $46 \mathrm{pmol} / \mathrm{L}$ ) patients with acute decompensated HF, respectively [76,77]; the multicentric MOLITOR study conducted on 164 patients admitted in hospital with a primary diagnosis of worsening HF identified in copeptin the best predictor of 90-day mortality or re-hospitalization (survivors vs. non-survivors/re-hospitalized: 26 vs. $47 \mathrm{pmol} / \mathrm{L}$ ), highlighting the prognostic superiority of copeptin on $\mathrm{N}$-terminalproBNP (NT-proBNP) both at admission and after serial assessments (after 72 and $48 \mathrm{~h}$ for copeptin and NT-proBNP, respectively) [78]; in patients referring to the emergency department with cardiogenic pulmonary edema, plasma copeptin levels were superior to NT-pro-BNP in predicting short-term mortality and, if $>40.1 \mathrm{pmol} / \mathrm{L}$, identified the presence of ARDS/acute lung injury with high specificity [79]. In a cohort of 268 patients with advanced HF copeptin was superior to BNP in predicting 24-month death or the composite outcome death and re-hospitalization (survivors vs. non survivors: 21 vs. $34 \mathrm{pmol} / \mathrm{L}$ ) [80], whereas in a large Italian cohort of 1237 patients with chronic and stable HF copeptin was found to be an independent predictor of mortality after a median 3.9-year follow-up, but with inferior prognostic accuracy than BNP [81]. Again, in the multicentric BACH study, which included more than 2000 patients presenting with acute dyspnea/HF, higher copeptin levels predicted 90-day mortality and re-hospitalizations independently, but with higher accuracy if combined with hyponatremia and with both sodium levels and NT-proBNP [82]; similarly, a complementary role of copeptin and high sensitivity Troponin $\mathrm{T}$ (hs-TnT) in predicting impaired clinical outcomes was found in patients with stable chronic HF [83]: if added to risk models containing NT-proBNP and hs-TnT, copeptin levels improved their prognostic performance. In the same patients, copeptin levels were directly correlated with symptoms severity according to the New York Heart Association (NYHA) classification [83], being also the most potent single predictor of 24-month mortality in patients of NYHA functional class II and III-the most challenging to treat in the outpatient setting-selected from a large cohort $(n=786)$ [84]. Adjustment for confounders improved the prognostic performance of copeptin in both the inpatient and outpatient settings $[85,86]$.

Copeptin has been also correlated to major outcomes in patients with acute myocardial infarction (AMI), where its plasma levels peak immediately after the event, reach a plateau between days 3 and 5 and have been correlated to the degree of left ventricular remodeling at echocardiography [87-89]. Higher median copeptin levels were found in patients who died or were re-admitted in hospital for HF after AMI (18.5 vs. 6.5 pmol/L in survivors, $p<0.0005)$; both copeptin and NT-proBNP were significant independent predictors of poor 60-day outcome (OR 4.14 and 2.26, respectively) [87]. A confirmation of these findings came from the OPTIMAAL study, where doubling copeptin levels with respect to baseline were associated to almost a 2-fold increased death risk, a 1.5-fold increased risk of composite cardiovascular endpoint and additive prognostic information came from the evaluation of change in copeptin levels after one month [88].

A single, simultaneous determination of both copeptin and $\operatorname{TnT}$ aimed at the very early rule-out of AMI has been tested widely in the latest years, but with conflicting results depending on the heterogeneous endpoints, patients' pre-test probability, timepoint of copeptin testing and cut-off values [90]. The first report on this topic came from 
Reichlin et al., who evaluated 492 patients referring to the emergency department for acute chest pain or anginal equivalents showing that plasma copeptin levels were significantly higher in patients with confirmed AMI than in patients with other diagnoses including unstable angina (20.8 vs. $6.0 \mathrm{pmol} / \mathrm{L})$ [91]. Among AMI patients referring within $2 \mathrm{~h}$ after the onset of chest pain, serial blood samples showed TnT and copeptin exhibited opposite kinetics, the former increasing $6 \mathrm{~h}$ after admission, the latter peaking at admission and decreasing within $6 \mathrm{~h}$. Moreover, no significant changes in copeptin levels were documented within $6 \mathrm{~h}$ in response to experimental balloon-induced ischemia in 34 patients with angiographically normal coronary arteries [92]. Therefore, copeptin measurement could provide additive information to TnT determination in early- rather than late-presenters [93-95]. Although not reported consistently [94], the best negative predictive value for the combined rule-out strategy seems to be achieved, thus leading safely to early discharge, in patients at low-to-intermediate pre-test risk for acute coronary syndrome, whether according to well-established scores [96-99] or the clinician's judgement $[100,101]$. In a prospective multicentric study comparing 14 different rule-out strategies, based on hs-Tn measurement in 3696 patients referring to the emergency department for suspected AMI, the dual-marker combination was questioned due to suboptimal performance [102]; however, this was not confirmed by a large pooled individual data analysis on 10,329 patients from five trials, where the combination of copeptin and hs-TnT resulted not only as safe and effective as the single low hs-TnT measurement, in both the instant rule-out of non-ST segment elevation myocardial infarction (NSTEMI) and prediction of 30-day all-cause mortality, but also more extensively applicable than very low hs-TnT-based strategies across special subgroups of patients (e.g., very early presenters, low-risk, impaired renal function etc.) [103]. Conversely, assessing copeptin in patients with STEMI could be of prognostic importance: findings from a cohort of 401 patients with STEMI undergoing primary percutaneous coronary intervention showed copeptin levels at admission were significantly higher in non-survivors than in survivors (154.8 vs. $30.3 \mathrm{pmol} / \mathrm{L}$ ) [104]. Moreover, in a cohort of more than 2000 patients with suspected STEMI, copeptin levels at admission were significantly higher in those complicating with cardiogenic shock (444 and $141 \mathrm{pmol} / \mathrm{L}$ in patients with early and late cardiogenic shock, respectively, vs. $55 \mathrm{pmol} / \mathrm{L}, p<0.0001$ ) and were independent predictors for late cardiogenic shock development, although with the lowest performance among the considered biomarkers (AUC 0.660 at cut-off values $>138 \mathrm{pmol} / \mathrm{L}$ ) [105]. Data from a recent metaanalysis including 2269 patients from six studies indicate copeptin may be of prognostic importance in overall acute coronary syndrome, since it has been associated to mortality with acceptable predictive performance (AUC 0.730) [106]. However, conditions coexisting with acute coronary syndrome could act as confounders for increased copeptin, whose superiority over the other well-established prognostic biomarkers is still not fully supported by evidence.

\subsection{Neurological Illnesses}

Acute physiological response to cerebral ischemia includes massive, biphasic activation of HPA axis, which has been related to the cytokine-mediated inflammatory response and associated to drowsiness, extent of brain damage and clinical outcome in patients with stroke [107-110]. Copeptin kinetics after acute ischemic stroke has been recently evaluated in 34 hospitalized patients [111]: it showed a peak at admission (50.71 pmol/L) and a subsequent, progressive decrease (18.31 pmol/L after $24 \mathrm{~h}, 10.92 \mathrm{pmol} / \mathrm{L}$ between day 3 and 5). Revascularized patients, particularly those receiving combined therapy, exhibited a steeper drop in copeptin levels within the first $24 \mathrm{~h}$ than patients treated conservatively $(-129.3$ vs. $-5.4 \mathrm{pmol} / \mathrm{L}, p=0.038)$. Copeptin levels $24 \mathrm{~h}$ from admission were significantly correlated with hemorrhagic transformation (93.1 vs. $13.7 \mathrm{pmol} / \mathrm{L}$ at $24 \mathrm{~h}$, 85.7 vs. $14.5 \mathrm{pmol} / \mathrm{L}$ between day 3 and 5), as well as with the degree of brain edema ( 32.3 vs. $13.7 \mathrm{pmol} / \mathrm{L}$ between day 3 and 5) as measured by computed tomography or magnetic resonance imaging. As a novel marker of neuro-humoral stress, copeptin has been 
investigated and its prognostic importance in terms of survival and functional outcomes has emerged consistently also in this context [112]. In a prospective, observational study conducted on 362 consecutive patients, copeptin was found to perform better than the commonly used indexes (glucose, CRP, white blood cell count, vital parameters) in predicting 90-day mortality and functional outcomes after acute ischemic stroke [113]; moreover, it was shown to improve the prognostic accuracy of the commonly used risk stratification tools, such as the National Institutes of Health Stroke Scale (NIHSS). Based on this, it has been recently included in a validated biomarker-based clinical score with age, NIHSS and thrombolysis, "the CoRisk score", for the prediction of 90-day death and disability after ischemic stroke (AUC 0.819) [114]. Data from a recent pooled analysis indicate copeptin is an independent predictor of stroke-associated pneumonia, although of only slightly additive value as compared with clinical parameters or commonly applied prediction scores $[115,116]$, and that its plasma levels are higher in cardioembolic stroke than other etiologies [115]. Furthermore, assessing copeptin levels in the emergency setting could be helpful in guiding the safe discharge of patients with transient ischemic attack (TIA) and their subsequent management as outpatients [117]: in a prospective observational study on 237 consecutive patients referring to the emergency department for TIA, copeptin emerged as an independent predictor for stroke recurrence within 7 days (negative predictive value $97.4 \%$ at a cut-off value of $13.8 \mathrm{pmol} / \mathrm{L}, \mathrm{HR} 3.9,95 \%$ CI 1.01-14.4, $p=0.039$ ), particularly when combined with demonstrated large artery atherosclerosis (HR 7.8, 95\% CI 2.5-24.7, $p=0.002$; AUC 0.83).

When 94 patients were followed-up for seven days after TBI, copeptin kinetics exhibited a rapid speed up during the first $6 \mathrm{~h}$ until a peak was reached in $24 \mathrm{~h}$, plateau levels were then maintained and $48 \mathrm{~h}$ after TBI hormonal secretion gradually decreased, albeit persisting more pronounced than in controls [38]. Copeptin levels at admission were inversely correlated with Glasgow Coma Scale (GCS) and significantly higher in non-survivors than in survivors (142 vs. $89 \mathrm{pmol} / \mathrm{L}$, respectively). Similarly to GCS, baseline copeptin was an independent predictor of 1-month mortality, with $89 \%$ sensitivity and $75 \%$ specificity at a cut-off of $112 \mathrm{pmol} / \mathrm{L}$. Studies conducted on patients referring to the emergency department for trauma showed that copeptin levels at admission were significantly higher in patients with polytrauma than healthy controls and had superior power than lactates in the early identification of major trauma, subsequent need for hospital admission and blood transfusion, but not of trauma-related mortality, need for emergency surgery or ICU admission. [39,118]. A meta-analysis including 2654 patients from 17 studies has recently confirmed previous findings, demonstrating not only a significant association between increased plasma copeptin levels and TBI, but also copeptin is of prognostic value in predicting brain concussion, progressive hemorrhagic injury, acute traumatic coagulopathy, mortality and poor functional outcomes in patients with TBI (AUC 0.83-0.90) [119].

With respect to healthy controls, plasma copeptin levels are elevated in patients with aneurysmal SAH (21.2 vs. $6.4 \mathrm{pmol} / \mathrm{L})$, where copeptin is also considered an independent predictor of both long-term poor functional outcome and mortality [40,41]: this is supported by the significant association found between higher plasma copeptin levels at hospital admission and severity of aneurysmal SAH according to well-established scores, such as the World Federation of Neurological Surgeons (WFNS) grading after resuscitation and the Fisher's score, as well as by the demonstration of higher plasma copeptin levels in non-survivors after aneurysmal SAH and in those with poor neurological outcome [40-42]. Specifically, Zuo and Ji found for each $1 \mathrm{pmol} / \mathrm{L}$ increase in plasma copeptin concentration, the adjusted risk of poor outcomes and mortality due to aneurysmal SAH would be increased by $6 \%$ and $9 \%$, respectively [42]. Moreover, the association between serial copeptin determinations and transcranial Doppler ultrasound was found to have a role in the screening of delayed cerebral ischemia after poor-grade SAH according to WFNS [44]. The prognostic value of copeptin in SAH has been recently confirmed in a systematic review by Jabbarli et al., which included copeptin among the 15 non-genetic predictors of delayed cerebral ischemia (level of evidence II) selected from a pool of 257 biomarkers, 
due to its significant correlations with delayed ischemic neurological deficits, angiographic vasospasm and vasospasm on transcranial Doppler ultrasound [43].

Studies on intraparenchymal hemorrhage obtained similar results, demonstrating higher plasma copeptin levels in patients than in controls [46], a hormonal kinetics overlapping with that observed in TBI patients [45], as well as associations between copeptin, short-term poor outcomes in terms of hematoma volume, neurological deterioration and both short-term and long-term patients' mortality [46,47].

A transient increase in copeptin levels has been recently documented immediately after generalized convulsive seizures both in adults and in children $[120,121]$, the former exhibiting a $>30$-fold increase at admission, a steep fall within $2 \mathrm{~h}$ and subsequent normalization $6 \mathrm{~h}$ after the acute event [120]. In the latter, copeptin levels reached a significant $>3$-fold and $>4$-fold elevation in epileptic and febrile seizures respectively, as compared with controls [121]; of note, prolactin levels differed significantly only between children with febrile seizures and controls.

\subsection{Birth Stress}

The delivery mode has a strong impact in the transition from intra-uterine to extrauterine life, which is driven by a dramatic, maternal labor-induced surge in fetal stress hormones in vaginal delivery [8]. Analysis of the umbilical cord blood of healthy newborns immediately after birth show copeptin concentrations are 1.8-fold higher in arterial than in venous plasma and data on anencephalic infants, as well as observation of their distribution pattern across the placenta support its fetal origin [122,123]. The main stimulus for copeptin release at birth is represented by neuronal hypoxia due to transient cerebral hypoperfusion caused by maternal uterine contractions: as a consequence of this, naturally delivered infants exhibit up to 100-fold higher copeptin levels than children born by cesarean section, regardless of gestational age at birth [122]; moreover, the latter show higher copeptin levels and if affected by intra-uterine growth restriction or if the cesarean section was needed due to complications than elective, thus strengthening the role for copeptin as a stress biomarker [124-126]. Activation of the AVP system at birth is aimed at providing to the newborn natural analgesia, tuning neurobehavior in complex interactions between central and peripheral nervous systems and preventing excessive dehydration and weight loss in the first postnatal days [8]: a correlation between copeptin levels and all these phenomena has been recently highlighted in studies involving humans (after-birth nociception and osmoregulation) or animals (after-birth osmoregulation and neurobehavior) [127-129].

\subsection{Psychological Stress}

The influence of psychological stress on copeptin in healthy individuals was also investigated. In the CoEXAM study, Urwyler et al. measured copeptin levels immediately before and after a written examination in 25 university students demonstrating a significant change between the two timepoints ( 3.1 vs. 2.3 pmol/L, $p<0.001$ ), which was also consistent with variations in serum and salivary cortisol, but unrelated to the examination performance [130]. Copeptin levels following standardized assessment of psychological stress by using the Trier Social Stress Test were determined in healthy volunteers, showing a significant increase from baseline to the immediate post-test period $(3.7 \rightarrow 5.1 \mathrm{pmol} / \mathrm{L}$ in Siegenthaler's cohort [131], about $+30 \%$ within 20 min in Spanakis's cohort [132], >2-fold increase within $15 \mathrm{~min}$ in Bae's cohort [133]) which was mainly related to feelings of tension and avoidance [131] and consistent with the increase in cortisol levels [131,132], although with a gender difference favoring males [132] and a weaker association with state anxiety and heart rate than salivary cortisone [133]. Surprisingly, data from a small observational study indicate copeptin seems not to account for psychological stress, anxiety and depression in women with fluid- and electrolyte-corrected severe anorexia nervosa [134], although an association between all the aforementioned disturbances and the chronic hyperactivation of HPA axis in anorexia nervosa was widely and consistently reported [135]. 


\section{Conclusions}

AVP and copeptin are released in equimolar amounts from the same precursor. Due to its molecular stability and countless advantages as compared with AVP, copeptin perfectly mirrors AVP's presence and has progressively emerged as a reliable marker of vasopressinergic activation in response to osmotic and hemodynamic stimuli in clinical practice. However, volemic and osmolar status can influence the interpretation of copeptin levels, accounting for the huge range of cut-offs encountered in several stress conditions and the lack of widely accepted predictive value for this biomarker in clinical practice. Nevertheless, evidence highlighting the prognostic potential of copeptin in several acute diseases, where the activation of AVP system is primarily linked to stress, as well as in psychologically stressful conditions has progressively emerged.

Author Contributions: Conceptualization M.M., G.A.; data curation M.M.; formal analysis M.M., G.A.; funding acquisition G.A.; investigation M.M., G.A.; methodology M.M., G.A.; project administration G.A.; resources M.M., G.A.; supervision G.A.; writing—original draft M.M., writing—review \& editing M.M., G.A. All authors have read and agreed to the published version of the manuscript.

Funding: The work was supported by the MIUR (Ministero dell'Istruzione dell'Università e della Ricerca), grant number HRTZYA_005, 2017.

Institutional Review Board Statement: Ethical review and approval were not applicable.

Informed Consent Statement: Not applicable.

Conflicts of Interest: The authors declare no conflict of interest.

\section{References}

1. Christ-Crain, M.; Fenske, W. Copeptin in the diagnosis of vasopressin-dependent disorders of fluid homeostasis. Nat. Rev. Endocrinol. 2016, 12, 168-176. [CrossRef]

2. Morgenthaler, N.G. Copeptin: A biomarker of cardiovascular and renal function. Congest. Heart Fail. 2010, 16 (Suppl. 1), S37-S44. [CrossRef]

3. Holwerda, D.A. A glycopeptide from the posterior lobe of pig pituitaries. I. Isolation and characterization. Eur. J. Biochem. 1972, 28, 334-339. [CrossRef] [PubMed]

4. Nagy, G.; Mulchahey, J.; Smyth, D.G.; Neill, J.D. The glycopeptide moiety of vasopressin-neurophysin precursor is neurohypophysial prolactin releasing factor. Biochem. Biophys. Res. Commun. 1988, 151, 524-529. [CrossRef]

5. Hyde, J.F.; North, W.G.; Ben-Jonathan, N. The vasopressin-associated glycopeptide is not a prolactin-releasing factor: Studies with lactating Brattleboro rats. Endocrinology 1989, 125, 35-40. [CrossRef]

6. Parodi, A.J. Protein glucosylation and its role in protein folding. Annu. Rev. Biochem. 2000, 69, 69-93. [CrossRef] [PubMed]

7. Barat, C.; Simpson, L.; Breslow, E. Properties of human vasopressin precursor constructs: Inefficient monomer folding in the absence of copeptin as a potential contributor to diabetes insipidus. Biochemistry 2004, 43, 8191-8203. [CrossRef] [PubMed]

8. Morgenthaler, N.G. Copeptin-Biochemistry and Clinical Diagnostics. In UNI-MED, 1st ed.; UNI-MED Verlag AG: Bremen, Germany, 2014; ISBN 978-3-8374-2286-3.

9. Fenske, W.K.; Schnyder, I.; Koch, G.; Walti, C.; Pfister, M.; Kopp, P.; Fassnacht, M.; Strauss, K.; Christ-Crain, M.J. Release and Decay Kinetics of Copeptin vs. AVP in Response to Osmotic Alterations in Healthy Volunteers. Clin. Endocrinol. Metab. 2018, 103, 505-513. [CrossRef]

10. Szinnai, G.; Morgenthaler, N.G.; Berneis, K.; Struck, J.; Müller, B.; Keller, U.; Christ-Crain, M.J. Changes in plasma copeptin, the c-terminal portion of arginine vasopressin during water deprivation and excess in healthy subjects. Clin. Endocrinol. Metab. 2007, 92, 3973-3978. [CrossRef]

11. Balanescu, S.; Kopp, P.; Gaskill, M.B.; Morgenthaler, N.G.; Schindler, C.; Rutishauser, J. Correlation of plasma copeptin and vasopressin concentrations in hypo-, iso-, and hyperosmolar States. J. Clin. Endocrinol. Metab. 2011, 96, 1046-1052. [CrossRef]

12. Morgenthaler, N.G.; Müller, B.; Struck, J.; Bergmann, A.; Redl, H.; Christ-Crain, M. Copeptin, a stable peptide of the arginine vasopressin precursor, is elevated in hemorrhagic and septic shock. Shock 2007, 28, 219-226. [CrossRef]

13. Melmed, S. The Pituitary. In Blackwell Science, 1st ed.; Blackwell Science: Hoboken, NJ, USA, 1995; ISBN 0-86542-126-9.

14. Melmed, S. The immuno-neuroendocrine interface. Series introduction. J. Clin. Investig. 2001, 108, 1563-1566. [CrossRef] [PubMed]

15. René, P.; de Keyzer, Y. The vasopressin receptor of corticotroph pituitary cells. Prog Brain Res. 2002, 139, 345-357.

16. Sivukhina, E.V.; Jirikowski, G.F. Magnocellular hypothalamic system and its interaction with the hypothalamo-pituitary-adrenal axis. Steroids 2016, 111, 21-28. [CrossRef] [PubMed] 
17. Otubo, A.; Kawakami, N.; Maejima, S.; Ueda, Y.; Morris, J.F.; Sakamoto, T.; Sakamoto, H. Vasopressin gene products are colocalised with corticotropin-releasing factor within neurosecretory vesicles in the external zone of the median eminence of the Japanese macaque monkey (Macaca fuscata). J. Neuroendocrinol. 2020, 32, e12875. [CrossRef] [PubMed]

18. Beglinger, S.; Drewe, J.; Christ-Crain, M. The Circadian Rhythm of Copeptin, the C-Terminal Portion of Arginine Vasopressin. J. Biomark. 2017, 2017, 4737082. [CrossRef] [PubMed]

19. Darzy, K.H.; Dixit, K.C.; Shalet, S.M.; Morgenthaler, N.G.; Brabant, G. Circadian secretion pattern of copeptin, the C-terminal vasopressin precursor fragment. Clin. Chem. 2010, 56, 1190-1191. [CrossRef]

20. Katan, M.; Morgenthaler, N.G.; Dixit, K.C.; Rutishauser, J.; Brabant, G.E.; Müller, B.; Christ-Crain, M. Anterior and posterior pituitary function testing with simultaneous insulin tolerance test and a novel copeptin assay. J. Clin. Endocrinol. Metab. 2007, 92, 2640-2643. [CrossRef]

21. Drummond, J.B.; Soares, B.S.; Pedrosa, W.; Vieira, E.L.M.; Teixeira, A.L.; Christ-Crain, M.; Ribeiro-Oliveira, A., Jr. Copeptin response to hypoglycemic stress is linked to prolactin activation in children. Pituitary 2020, 23, 681-690. [CrossRef]

22. Lewandowski, K.C.; Lewiński, A.; Skowrońska-Jóźwiak, E.; Stasiak, M.; Horzelski, W.; Brabant, G. Copeptin under glucagon stimulation. Endocrine 2016, 52, 344-351. [CrossRef]

23. Kacheva, S.; Kolk, K.; Morgenthaler, N.G.; Brabant, G.; Karges, W. Gender-specific co-activation of arginine vasopressin and the hypothalamic-pituitary-adrenal axis during stress. Clin. Endocrinol. 2015, 82, 570-576. [CrossRef]

24. Robertson, G.L.; Mahr, E.A.; Athar, S.; Sinha, T. Development and clinical application of a new method for the radioimmunoassay of arginine vasopressin in human plasma. J. Clin. Investig. 1973, 52, 2340-2352. [CrossRef]

25. Kluge, M.; Riedl, S.; Erhart-Hofmann, B.; Hartmann, J.; Waldhauser, F. Improved extraction procedure and RIA for determination of arginine-vasopressin in plasma: Role of premeasurement sample treatment and reference values in children. Clin. Chem. 1999, 45, 98-103. [CrossRef] [PubMed]

26. Morgenthaler, N.G.; Struck, J.; Alonso, C.; Bergmann, A. Assay for the measurement of copeptin, a stable peptide derived from the precursor of vasopressin. Clin. Chem. 2006, 52, 112-119. [CrossRef] [PubMed]

27. Walti, C.; Siegenthaler, J.; Christ-Crain, M. Copeptin levels are independent of ingested nutrient type after standardised meal administration-the CoMEAL study. Biomarkers 2014, 19, 557-562. [CrossRef] [PubMed]

28. Blum, C.A.; Mirza, U.; Christ-Crain, M.; Mueller, B.; Schindler, C.; Puder, J.J. Copeptin levels remain unchanged during the menstrual cycle. PLoS ONE 2014, 9, e98240. [CrossRef]

29. Roussel, R.; Fezeu, L.; Marre, M.; Velho, G.; Fumeron, F.; Jungers, P.; Lantieri, O.; Balkau, B.; Bouby, N.; Bankir, L.; et al. Comparison between copeptin and vasopressin in a population from the community and in people with chronic kidney disease. J. Clin. Endocrinol. Metab. 2014, 99, 4656-4663. [CrossRef] [PubMed]

30. Christ-Crain, M. Vasopressin and Copeptin in health and disease. Rev. Endocr. Metab. Disord. 2019, 20, 283-294. [CrossRef]

31. Morgenthaler, N.G.; Struck, J.; Jochberger, S.; Dünser, M.W. Copeptin: Clinical use of a new biomarker. Trends Endocrinol. Metab. 2008, 19, 43-49. [CrossRef]

32. Katan, M.; Christ-Crain, M. The stress hormone copeptin: A new prognostic biomarker in acute illness. Swiss Med. Wkly. 2010, 140, w13101. [CrossRef]

33. Struck, J.; Morgenthaler, N.G.; Bergmann, A. Copeptin, a stable peptide derived from the vasopressin precursor, is elevated in serum of sepsis patients. Peptides 2005, 26, 2500-2504. [CrossRef]

34. Jochberger, S.; Morgenthaler, N.G.; Mayr, V.D.; Luckner, G.; Wenzel, V.; Ulmer, H.; Schwarz, S.; Hasibeder, W.R.; Friesenecker, B.E.; Dünser, M.W. Copeptin and arginine vasopressin concentrations in critically ill patients. J. Clin. Endocrinol. Metab. 2006, 91, 4381-4386. [CrossRef] [PubMed]

35. Zhang, Q.; Dong, G.; Zhao, X.; Wang, M.; Li, C.S. Prognostic significance of hypothalamic-pituitary-adrenal axis hormones in early sepsis: A study performed in the emergency department. Intensive Care Med. 2014, 40, 1499-1508. [CrossRef] [PubMed]

36. Mazzeo, A.T.; Guaraldi, F.; Filippini, C.; Tesio, R.; Settanni, F.; Lucchiari, M.; Mengozzi, G.; Grottoli, S.; Ghigo, E.; Mascia, L. Activation of pituitary axis according to underlying critical illness and its effect on outcome. J. Crit. Care 2019, 54, 22-29. [CrossRef] [PubMed]

37. Zampino, R.; Iossa, D.; Ursi, M.P.; Bertolino, L.; Andini, R.; Molaro, R.; Fabrazzo, O.; Leonardi, S.; Atripaldi, L.; Durante-Mangoni, E. Prognostic value of pro-adrenomedullin and copeptin in acute infective endocarditis. BMC Infect. Dis. 2021, 21, 23. [CrossRef]

38. Dong, X.Q.; Huang, M.; Yang, S.B.; Yu, W.H.; Zhang, Z.Y. Copeptin is associated with mortality in patients with traumatic brain injury. J. Trauma 2011, 71, 1194-1198. [CrossRef]

39. Zhang, J.; Wang, H.; Li, Y.; Zhang, H.; Liu, X.; Zhu, L.; Dong, L. The diagnosis and prognostic value of plasma copeptin in traumatic brain injury: A systematic review and meta-analysis. Neurol. Sci. 2021, 42, 539-551. [CrossRef]

40. Zhu, X.D.; Chen, J.S.; Zhou, F.; Liu, Q.C.; Chen, G.; Zhang, J.M. Detection of copeptin in peripheral blood of patients with aneurysmal subarachnoid hemorrhage. Crit. Care 2011, 15, R288. [CrossRef]

41. Fung, C.; De Marchis, G.M.; Katan, M.; Seiler, M.; Arnold, M.; Gralla, J.; Raabe, A.; Beck, J. Copeptin as a marker for severity and prognosis of aneurysmal subarachnoid hemorrhage. PLoS ONE 2013, 8, e53191. [CrossRef]

42. Zuo, Z.; Ji, X. Prognostic value of copeptin in patients with aneurysmal subarachnoid hemorrhage. J. Neuroimmunol. 2019, 330, 116-122. [CrossRef] 
43. Jabbarli, R.; Pierscianek, D.; Darkwah Oppong, M.; Sato, T.; Dammann, P.; Wrede, K.H.; Kaier, K.; Köhrmann, M.; Forsting, M.; Kleinschnitz, C.; et al. Laboratory biomarkers of delayed cerebral ischemia after subarachnoid hemorrhage: A systematic review. Neurosurg. Rev. 2020, 43, 825-833. [CrossRef]

44. Rhim, J.K.; Youn, D.H.; Kim, B.J.; Kim, Y.; Kim, S.; Kim, H.C.; Jeon, J.P. The Role of Consecutive Plasma Copeptin Levels in the Screening of Delayed Cerebral Ischemia in Poor-Grade Subarachnoid Hemorrhage. Life 2021, 11, 274. [CrossRef]

45. Dong, X.; Huang, M.; Yu, W.; Zhang, Z.; Zhu, Q.; Che, Z.; Du, Q.; Wang, H. Change in plasma copeptin level after acute spontaneous basal ganglia hemorrhage. Peptides 2011, 32, 253-257. [CrossRef]

46. Zhang, X.; Lu, X.; Huang, L.; Ye, H. Copeptin is associated with one-year mortality and functional outcome in patients with acute spontaneous basal ganglia hemorrhage. Peptides 2012, 33, 336-341. [CrossRef]

47. Zhang, A.; Li, J.; Li, X.; Song, L.; Li, H. The prognostic value of copeptin for acute intracerebral hemorrhage patients. Exp. Ther. Med. 2013, 5, 467-470. [CrossRef] [PubMed]

48. Colson, P.H.; Bernard, C.; Struck, J.; Morgenthaler, N.G.; Albat, B.; Guillon, G. Post cardiac surgery vasoplegia is associated with high preoperative copeptin plasma concentration. Crit. Care 2011, 15, R255. [CrossRef] [PubMed]

49. Braun, S.D.; Juhn, M.; Bergmann, S.; Katzke, S.; Weise, M.; Alakel, N.; Stölzel, F.; Kroschinsky, F.; Ehninger, G.; Höffken, G.; et al. Net reclassification improvement with serial biomarkers and bedsided spirometry to early predict the need of organ support during the early post-transplantation in-hospital stay in allogeneic HCT recipients. Bone Marrow Transpl. 2019, 54, 265-274. [CrossRef] [PubMed]

50. Pasero, D.; Berton, A.M.; Motta, G.; Raffaldi, R.; Fornaro, G.; Costamagna, A.; Toscano, A.; Fllippini, C.; Mengozzi, G.; Prencipe, N.; et al. Neuroendocrine predictors of vasoplegia after cardiopulmonary bypass. J. Endocrinol. Invest. 2020, 44, $1533-1541$. [CrossRef] [PubMed]

51. Ristagno, G.; Latini, R.; Plebani, M.; Zaninotto, M.; Vaahersalo, J.; Masson, S.; Tianinen, M.; Kurola, J.; Gaspari, F.; Milani, V.; et al. Copeptin levels are associated with organ dysfunction and death in the intensive care unit after out-of-hospital cardiac arrest. Crit. Care 2015, 19, 132. [CrossRef] [PubMed]

52. Düring, J.; Annborn, M.; Cronberg, T.; Dankiewicz, J.; Devaux, Y.; Hassager, C.; Horn, J.; Kjaergaard, J.; Kuiper, M.; Nikoukhah, H.R.; et al. Copeptin as a marker of outcome after cardiac arrest: A sub-study of the TTM trial. Crit Care. 2020, 24, 185. [CrossRef]

53. Paramanathan, S.; Grejs, A.M.; Jeppesen, A.N.; Søreide, E.; Kirkegaard, H.; Duez, C.H.V. Copeptin as a Prognostic Marker in Prolonged Targeted Temperature Management after Out-of-Hospital Cardiac Arrest. Ther. Hypothermia Temp. Manag. 2020. [CrossRef]

54. Kalkan, A.K.; Ozturk, D.; Erturk, M.; Kalkan, M.E.; Cakmak, H.A.; Oner, E.; Uzun, F.; Tasbulak, O.; Yakisan, T.; Celik, A. The diagnostic value of serum copeptin levels in an acute pulmonary embolism. Cardiol. J. 2016, 23, 42-50. [CrossRef] [PubMed]

55. Wyzgał, A.; Koć, M.; Pacho, S.; Bielecki, M.; Wawrzyniak, R.; Kostrubiec, M.; Ciurzyński, M.; Kurnicka, K.; Goliszek, S.; Paczyńska, M.; et al. Plasma copeptin for short term risk stratification in acute pulmonary embolism. J. Thromb. Thrombolys. 2016, 41, 563-568. [CrossRef] [PubMed]

56. Hellenkamp, K.; Schwung, J.; Rossmann, H.; Kaeberich, A.; Wachter, R.; Hasenfuß, G.; Konstantinides, S.; Lankeit, M. Risk stratification of normotensive pulmonary embolism: Prognostic impact of copeptin. Eur. Respir. J. 2015, 46, 1701-1710. [CrossRef]

57. Hellenkamp, K.; Pruszczyk, P.; Jiménez, D.; Wyzgał, A.; Barrios, D.; Ciurzyński, M.; Morillo, R.; Hobohm, L.; Keller, K.; Kurnicka, K.; et al. Prognostic impact of copeptin in pulmonary embolism: A multicentre validation study. Eur. Respir. J. 2018, 53. [CrossRef] [PubMed]

58. Deveci, F.; Öner, Ö.; Telo, S.; Kırkıl, G.; Balin, M.; Kuluöztürk, M. Prognostic value of copeptin in patients with acute pulmonary thromboembolism. Clin. Respir. J. 2019, 13, 630-636. [CrossRef]

59. Muller, B.; Morgenthaler, N.; Stolz, D.; Schuetz, P.; Müller, C.; Bingisser, R.; Bergmann, A.; Tamm, M.; Christ-Crain, M. Circulating levels of copeptin, a novel biomarker, in lower respiratory tract infections. Eur. J. Clin. Investig. 2007, 37, 145-152. [CrossRef] [PubMed]

60. Krüger, S.; Papassotiriou, J.; Marre, R.; Richter, K.; Schumann, C.; von Baum, H.; Morgenthaler, N.G.; Suttorp, R.; Welte, T.; CAPNETZ Study Group. Pro-atrial natriuretic peptide and pro-vasopressin to predict severity and prognosis in communityacquired pneumonia: Results from the German competence network CAPNETZ. Intensive Care Med. 2007, 33, 2069-2078. [CrossRef] [PubMed]

61. Masiá, M.; Papassotiriou, J.; Morgenthalr, N.G.; Hernández, I.; Shum, C.; Gutiérrez, F. Midregional pro-A-type natriuretic peptide and carboxy-terminal provasopressin may predict prognosis in community-acquired pneumonia. Clin. Chem. 2007, 53, $2193-2201$. [CrossRef] [PubMed]

62. Schuetz, P.; Wolbers, M.; Christ-Crain, M.; Thomann, R.; Falconnier, C.; Widmer, I.; Neidert, S.; Fricker, T.; Blum, C.; Schild, U. Prohormones for prediction of adverse medical outcome in community-acquired pneumonia and lower respiratory tract infections. Crit. Care 2010, 14, R106. [CrossRef]

63. Kruger, S.; Ewig, S.; Kunde, J.; Hartmann, O.; Suttorp, N.; Welte, T.; CAPNETZ Study Group. Pro-atrial natriuretic peptide and pro-vasopressin for predicting short-term and long-term survival in community-acquired pneumonia: Results from the German Competence Network CAPNETZ. Thorax 2010, 65, 208-214. [CrossRef] [PubMed]

64. Kolditz, M.; Ewig, S.; Hoffken, G. Management-based risk prediction in community-acquired pneumonia by scores and biomarkers. Eur. Respir. J. 2013, 41, 974-984. [CrossRef] [PubMed] 
65. Stolz, D.; Christ-Crain, M.; Morgenthaler, N.G.; Leuppi, J.; Miedinger, D.; Bingisser, R.; Müller, C.; Struck, J.; Müller, B.; Tamm, M. Copeptin, C-reactive protein, and procalcitonin as prognostic biomarkers in acute exacerbation of COPD. Chest 2007, 131, 1058-1067. [CrossRef]

66. Wojsyk-Banaszak, I.; Sobkowiak, P.; Jończyk-Potoczna, K.; Narożna, B.; Langwiński, W.; Szczepanik, M.; Kycler, Z.; Bręborowicz, A.; Szczepankiewicz, A. Evaluation of Copeptin during Pulmonary Exacerbation in Cystic Fibrosis. Mediat. Inflamm. 2019, 2019, 1939740. [CrossRef]

67. Kuluöztürk, M.; İn, E.; Telo, S.; Karabulut, E.; Geçkil, A.A. Efficacy of copeptin in distinguishing COVID-19 pneumonia from community-acquired pneumonia. J. Med. Virol. 2021, 93, 3113-3121. [CrossRef] [PubMed]

68. Karakioulaki, M.; Grendelmeier, P.; Strobel, W.; Schmid, T.; Jahn, K.; Grize, L.; Tamm, M.; Stolz, D. Copeptin, pro-atrial natriuretic peptide and pro-adrenomedullin as markers of hypoxic stress in patients with obstructive sleep apnea-A prospective intervention study. Respir. Res. 2021, 22, 114. [CrossRef]

69. Cinarka, H.; Kayah, S.; Karatas, M.; Yavuz, A.; Gümüş, A.; Özyurt, S.; Cüre, M.C.; Şahin, Ü. Copeptin: A new predictor for severe obstructive sleep apnea. Ther. Clin. Risk Manag. 2015, 11, 589-594.

70. Osma, Ü.; Selçuk, Ö.T.; Eyigör, M.; Renda, L.; Selçuk, N.T.; Eyigör, H.; Yılmaz, M.D.; İlden, O.; Işık, Ü.G.; Ünlü, H.K.; et al. Do serum copeptin levels change with positive airway pressure treatment in patients with severe obstructive sleep apnea? Tr-ENT 2020, 30, 52-57. [CrossRef]

71. Selçuk, Ö.T.; Eyigör, M.; Renda, L.; Osma, U.; Eyigor, H.; Selcuk, N.T.; Yılmaz, M.D.; Demirkıran, C.; Unlu, H.; Gültekin, M. Can we use serum copeptin levels as a biomarker in obstructive sleep apnea syndrome? J. Craniomaxillofac. Surg. 2015, 43, 879-882. [CrossRef]

72. Dobsa, L.; Cullen Edozien, K. Copeptin and its potential role in diagnosis and prognosis of various diseases. Biochem. Med. 2013, 23, 172-190. [CrossRef]

73. Bolignano, D.; Cabassi, A.; Fiaccadori, E.; Ghigo, E.; Pasquali, R.; Peracino, A.; Peri, A.; Plebani, M.; Santoro, A.; Settanni, F.; et al. Copeptin (CTproAVP), a new tool for understanding the role of vasopressin in patophysiology. Clin. Chem. Lab. Med. 2014, 52, 1447-1456. [CrossRef] [PubMed]

74. Zhong, Y.; Wang, R.; Yan, L.; Lin, M.; Liu, X.; You, T. Copeptin in heart failure: Review and meta-analysis. Clin. Chim. Acta 2017, 475, 36-43. [CrossRef] [PubMed]

75. Zabarovskaja, S.; Hage, C.; Gabrielsen, A.; Mellbin, L.; Lund, L.H. Copeptin in Heart Failure, Post-Left Ventricular Assist Device and Post-Heart Transplantation. Heart Lung Circ. 2017, 26, 143-149. [CrossRef] [PubMed]

76. Ozmen, C.; Deveci, O.S.; Tepe, O.; Yesildas, C.; Ünal, I.; Yıldız, I.; Akıllı, R.E.; Deniz, A.; Demir, M.; Kanadaşı, M.; et al. Prognostic performance of copeptin among patients with acute decompensated heart failure. Acta Cardiol. 2020. [CrossRef]

77. Gegenhuber, A.; Struck, J.; Dieplinger, B.; Poelz, W.; Pacher, R.; Morgenthaler, N.G.; Bergmann, A.; Haltmayer, M.; Mueller, T. Comparative evaluation of B-type natriuretic peptide, mid-regional pro-A-type natriuretic peptide, mid-regional pro-adrenomedullin, and Copeptin to predict 1-year mortality in patients with acute destabilized heart failure. J. Card. Fail. 2007, 13, 42-49. [CrossRef]

78. Dungen, H.D.; Tscholl, V.; Obradovic, D.; Radenovic, S.; Matic, D.; Musial Bright, L.; Tahirovic, E.; Marx, A.; Inkrot, S.; Hashemi, D.; et al. Prognostic performance of serial in-hospital measurements of copeptin and multiple novel biomarkers among patients with worsening heart failure: Results from the MOLITOR study. ESC Heart Fail. 2018, 5, 288-296. [CrossRef] [PubMed]

79. Lin, Q.; Fu, F.; Chen, H.; Zhu, B. Copeptin in the assessment of acute lung injury and cardiogenic pulmonary edema. Respir. Med. 2012, 106, 1268-1277. [CrossRef]

80. Stoiser, B.; Mörtl, D.; Hülsmann, M.; Berger, R.; Struck, J.; Morgenthaler, N.G.; Bergmann, A.; Pacher, R. Copeptin, a fragment of the vasopressin precursor, as a novel predictor of outcome in heart failure. Eur. J. Clin. Investig. 2006, 36, 771-778. [CrossRef] [PubMed]

81. Masson, S.; Latini, R.; Carbonieri, E.; Moretti, L.; Rossi, M.G.; Ciricugno, S.; Milani, V.; Marchioli, R.; Struck, J.; Bergmann, A.; et al. GISSI-HF Investigators. The predictive value of stable precursor fragments of vasoactive peptides in patients with chronic heart failure: Data from the GISSI-heart failure (GISSI-HF) trial. Eur. J. Heart Fail. 2010, 12, 338-347. [CrossRef]

82. Maisel, A.; Xue, Y.; Shah, K.; Mueller, C.; Nowak, R.; Peacock, W.F.; Ponikowski, P.; Mockel, M.; Hogan, C.; Wu, A.H.; et al. Increased 90-day mortality in patients with acute heart failure with elevated copeptin: Secondary results from the Biomarkers in Acute Heart Failure (BACH) study. Circ. Heart Fail. 2011, 4, 613-620. [CrossRef] [PubMed]

83. Tentzeris, I.; Jarai, R.; Farhan, S.; Perkmann, T.; Schwarz, M.A.; Jakl, G.; Wojta, J.; Huber, K. Complementary role of copeptin and high-sensitivity troponin in predicting outcome in patients with stable chronic heart failure. Eur. J. Heart Fail. 2011, 13, 726-733. [CrossRef] [PubMed]

84. Neuhold, S.; Huelsmann, M.; Strunk, G.; Stoiser, B.; Struck, J.; Morgenthaler, N.G.; Bergmann, A.; Moertl, D.; Berger, R.; Pacher, R. Comparison of copeptin, B-type natriuretic peptide, and amino-terminal pro-B-type natriuretic peptide in patients with chronic heart failure: Prediction of death at different stages of the disease. J. Am. Coll. Cardiol. 2008, 52, 266-272. [CrossRef]

85. Yoshikawa, Y.; Shiomi, H.; Kuwahara, K.; Sowa, N.; Yaku, H.; Yamashita, Y.; Tazaki, J.; Imai, M.; Kato, T.; Saito, N.; et al. Utility of copeptin for predicting long-term clinical outcomes in patients with heart failure. J. Cardiol. 2019, 73, 379-385. [CrossRef]

86. Miller, W.L.; Grill, D.E.; Struck, J.; Jaffe, A.S. Association of hyponatremia and elevated copeptin with death and need for transplantation in ambulatory patients with chronic heart failure. Am. J. Cardiol. 2013, 111, 880-885. [CrossRef] 
87. Khan, S.Q.; Dhillon, O.S.; O’Brien, R.J.; Struck, J.; Quinn, P.A.; Morgenthaler, N.G.; Squire, I.B.; Davies, J.E.; Bergmann, A.; $\mathrm{Ng}$, L.L. C-terminal provasopressin (copeptin) as a novel and prognostic marker in acute myocardial infarction: Leicester Acute Myocardial Infarction Peptide (LAMP) study. Circulation 2007, 115, 2103-2110. [CrossRef]

88. Voors, A.A.; von Haehling, S.; Anker, S.D.; Hillege, H.L.; Struck, J.; Hartmann, O.; Bergmann, A.; Squire, I.; Van Veldhuisen, D.J.; Dickstein, K. OPTIMAAL Investigators. C-terminal provasopressin (copeptin) is a strong prognostic marker in patients with heart failure after an acute myocardial infarction: Results from the OPTIMAAL study. Eur. Heart J. 2009, 30, 1187-1194. [PubMed]

89. Kelly, D.; Squire, I.B.; Khan, S.Q.; Quinn, P.; Struck, J.; Morgenthaler, N.G.; Davies, J.E. C-terminal provasopressin (copeptin) is associated with left ventricular dysfunction, remodeling, and clinical heart failure in survivors of myocardial infarction. J. Card. Fail. 2008, 14, 739-745. [CrossRef]

90. Möckel, M.; Searle, J. Copeptin-marker of acute myocardial infarction. Curr. Atheroscler. Rep. 2014, 16, 421. [CrossRef]

91. Reichlin, T.; Hochholzer, W.; Stelzig, C.; Laule, K.; Freidank, H.; Morgenthaler, N.G.; Bergmann, A.; Potocki, M.; Noveanu, M.; Breidthardt, T.; et al. Incremental value of copeptin for rapid rule out of acute myocardial infarction. J. Am. Coll. Cardiol. 2009, 54, 60-68. [CrossRef] [PubMed]

92. Keller, T.; Tzikas, S.; Zeller, T.; Czyz, E.; Lillpopp, L.; Ojeda, F.M.; Roth, A.; Bickel, C.; Baldus, S.; Sinning, C.R.; et al. Copeptin improves early diagnosis of acutemyocardial infarction. J. Am. Coll. Cardiol. 2010, 55, 2096-2106. [CrossRef]

93. Karakas, M.; Januzzi, J.L., Jr.; Meyer, J.; Lee, H.; Schlett, C.L.; Truong, Q.A.; Rottbauer, W.; Bamberg, F.; Dasdemir, S.; Hoffmann, U.; et al. Copeptin does not add diagnostic information to high-sensitivity troponin $\mathrm{T}$ in low-to intermediate-risk patients with acute chest pain: Results from the Rule Out Myocardial Infarction by Computed Tomography (ROMICAT) study. Clin. Chem. 2011, 57, 1137-1145. [CrossRef]

94. Bahrmann, P.; Bahrmann, A.; Breithardt, O.A.; Daniel, W.G.; Christ, M.; Sieber, C.C.; Bertsch, T. Additional diagnostic and prognostic value of copeptin ultra-sensitive for diagnosis of non-ST-elevation myocardial infarction in older patients presenting to the emergency department. Clin. Chem. Lab. Med. 2013, 51, 1307-1319. [CrossRef] [PubMed]

95. Árnadóttir, Á.; Pedersen, S.; Bo Hasselbalch, R.; Goetze, J.P.; Friis-Hansen, L.J.; Bloch-Münster, A.M.; Skov Jensen, J.; Bundgaard, H.; Iversen, K. Temporal Release of High-Sensitivity Cardiac Troponin T and I and Copeptin After Brief Induced Coronary Artery Balloon Occlusion in Humans. Circulation 2021, 143, 1095-1104. [CrossRef] [PubMed]

96. Bohyn, E.; Dubie, E.; Lebrun, C.; Jund, J.; Beaune, G.; Lesage, P.; Belle, L.; Savary, D. Expeditious exclusion of acute coronary syndrome diagnosis by combined measurements of copeptin, highsensitivity troponin, and GRACE score. Am. J. Emerg. Med. 2014, 32, 293-296. [CrossRef] [PubMed]

97. Möckel, M.; Searle, J.; Hamm, C.; Slagman, A.; Blankenberg, S.; Huber, K.; Katus, H.; Liebetrau, C.; Müller, C.; Muller, R.; et al. Early discharge using single cardiac troponin and copeptin testing in patients with suspected acute coronary syndrome (ACS): A randomized, controlled clinical process study. Eur. Heart J. 2014, 36, 369-376. [CrossRef] [PubMed]

98. Mueller-Hennessen, M.; Lindahl, B.; Giannitsis, E.; Vafaie, M.; Biener, M.; Haushofer, A.C.; Seier, J.; Christ, M.; Alquézar-Arbé, A.; deFilippi, C.R.; et al. Combined testing of copeptin and high-sensitivity cardiac troponin $\mathrm{T}$ at presentation in comparison to other algorithms for rapid rule-out of acute myocardial infarction. Int. J. Cardiol. 2019, 276, 261-267. [CrossRef]

99. Giannitsis, E.; Clifford, P.; Slagman, A.; Ruedelstein, R.; Liebetrau, C.; Hamm, C.; Honnart, D.; Huber, K.; Vollert, J.O.; Simonelli, C.; et al. Multicentre cross-sectional observational registry to monitor the safety of early discharge after rule-out of acute myocardial infarction by copeptin and troponin: The Pro-Core registry. BMJ Open 2019, 9, e028311. [CrossRef]

100. Maisel, A.; Mueller, C.; Neath, S.X.; Christenson, R.H.; Morgenthaler, N.G.; McCord, J.; Nowak, R.M.; Vilke, G.; Daniels, L.B.; Hollander, J.E.; et al. Copeptin helps in the early detection of patients with acute myocardial infarction: Primary results of the CHOPIN trial (Copeptin Helps in the early detection Of Patients with acute myocardial INfarction). J. Am. Coll. Cardiol. 2013, 62, 150-160. [CrossRef]

101. Chenevier-Gobeaux, C.; Freund, Y.; Claessens, Y.E.; Guerin, S.; Bonnet, P.; Doumenc, B.; Leumani, F.; Cosson, C.; Allo, J.C.; Riou, B.; et al. Copeptin for rapid rule out of acute myocardial infarction in emergency department. Int. J. Cardiol. 2013, 166, 198-204. [CrossRef]

102. Wildi, K.; Boeddinghaus, J.; Nestelberger, T.; Twerenbold, R.; Badertscher, P.; Wussler, D.; Giménez, M.R.; Puelacher, C.; de Lavallaz, J.D.F.; Dietsche, S.; et al. Comparison of fourteen rule-out strategies for acute myocardial infarction. Int. J. Cardiol. 2019, 283, 41-47. [CrossRef]

103. Giannitsis, E.; Huber, K.; Hamm, C.W.; Möckel, M. Instant rule-out of suspected non-ST-segment elevation myocardial infarction using high-sensitivity cardiac troponin $\mathrm{T}$ with Copeptin versus a single low high-sensitivity cardiac troponin T: Findings from a large pooled individual data analysis on 10,329 patients. Clin. Res. Cardiol. 2021, 110, 194-199. [PubMed]

104. Lattuca, B.; Sy, V.; Nguyen, L.S.; Bernard, M.; Zeitouni, M.; Overtchouk, P.; Yan, Y.; Hammoudi, N.; Ceccaldi, A.; Collet, J.P.; et al. Copeptin as a prognostic biomarker in acute myocardial infarction. Int. J. Cardiol. 2019, 274, 337-341. [CrossRef]

105. Frydland, M.; Møller, J.E.; Lindholm, M.G.; Hansen, R.; Wiberg, S.; Lerche Helgestad, O.K.; Thomsen, J.H.; Goetze, J.P.; Engstrøm, T.; Frikke-Schmidt, R.; et al. Biomarkers predictive of late cardiogenic shock development in patients with suspected ST-elevation myocardial infarction. Eur. Heart J. Acute Cardiovasc. Care. 2020, 9, 557-566. [CrossRef]

106. Lu, J.; Wang, S.; He, G.; Wang, Y. Prognostic value of copeptin in patients with acute coronary syndrome: A systematic review and meta-analysis. PLoS ONE 2020, 15, e0238288. [CrossRef]

107. Johansson, A.; Olsson, T.; Carlberg, B.; Karlsson, K.; Fagerlund, M. Hypercortisolism after stroke-partly cytokine-mediated? J. Neurol. Sci. 1997, 147, 43-47. [CrossRef] 
108. Johansson, A.; Ahren, B.; Nasman, B.; Carlstrom, K.; Olsson, T. Cortisol axis abnormalities early after stroke-relationships to cytokines and leptin. J. Intern. Med. 2000, 247, 179-187. [CrossRef] [PubMed]

109. Slowik, A.; Turaj, W.; Pankiewicz, J.; Dziedzic, T.; Szermer, P.; Szczudlik, A. Hypercortisolemia in acute stroke is related to the inflammatory response. J. Neurol. Sci. 2002, 196, 27-32. [CrossRef]

110. Fassbender, K.; Schmidt, R.; Mossner RDaffertshofer, M.; Hennerici, M. Pattern of activation of the hypothalamic-pituitaryadrenal axis in acute stroke. Relation to acute confusional state, extent of brain damage, and clinical outcome. Stroke 1994, 25, 1105-1108. [CrossRef]

111. Spagnolello, O.; De Michele, M.; Lorenzano, S.; Cerulli Irelli, E.; Naitana, F.; Falcou, A.; Letteri, F.; Bachetoni, A.; Collepardo, D.; Bertazzoni, G.; et al. Copeptin Kinetics in Acute Ischemic Stroke May Differ According to Revascularization Strategies: Pilot Data. Stroke 2019, 50, 3632-3635. [CrossRef] [PubMed]

112. Montellano, F.A.; Ungethüm, K.; Ramiro, L.; Nacu, A.; Hellwig, S.; Fluri, F.; Whiteley, W.N.; Bustamante, A.; Montaner, J.; Heuschmann, P.U. Role of Blood-Based Biomarkers in Ischemic Stroke Prognosis: A Systematic Review. Stroke 2021, 52, 543-551. [CrossRef] [PubMed]

113. Katan, M.; Fluri, F.; Morgenthaler, N.G.; Schuetz, P.; Zweifel, C.; Bingisser, R.; Müller, K.; Meckel, S.; Gass, A.; Kappos, L.; et al. Copeptin: A novel, independent prognostic marker in patients with ischemic stroke. Ann. Neurol. 2009, 66, 799-808. [CrossRef]

114. De Marchis, G.M.; Dankowski, T.; König, I.R.; Fladt, J.; Fluri, F.; Gensicke, H.; Foerch, C.; Findling, O.; Kurmann, R.; Fischer, U.; et al. A novel biomarker-based prognostic score in acute ischemic stroke: The CoRisk score. Neurology 2019, 92, e1517-e1525. [CrossRef]

115. Hotter, B.; Hoffmann, S.; Ulm, L.; Montaner, J.; Bustamante, A.; Meisel, C.; Meisel, A. Inflammatory and stress markers predicting pneumonia, outcome, and etiology in patients with stroke: Biomarkers for predicting pneumonia, functional outcome, and death after stroke. Neurol. Neuroimmunol. Neuroinflamm. 2020, 7, e692. [CrossRef]

116. Hotter, B.; Hoffmann, S.; Ulm, L.; Meisel, C.; Bustamante, A.; Montaner, J.; Katan, M.; Smith, C.J.; Meisel, A. External Validation of Five Scores to Predict Stroke-Associated Pneumonia and the Role of Selected Blood Biomarkers. Stroke 2021, 52, 325-330. [CrossRef]

117. Purroy, F.; Suárez-Luis, I.; Cambray, S.; Farré, J.; Benabdelhak, I.; Mauri-Capdevila, G.; Sanahuja, J.; Quílez, A.; Begué, R.; Gil, M.I.; et al. The determination of copeptin levels helps management decisions among transient ischaemic attack patients. Acta Neurol. Scand. 2016, 134, 140-147. [CrossRef]

118. Westermann, I.; Mw, D.; Haas, T.; Jochberger, S.; Luckner, G.; Mayr, V.; Wenzel, V.; Kh, S.; Innerhofer, P.; Morgenthaler, N.; et al. Endogenous vasopressin and copeptin response in multiple trauma patients. Shock 2007, 28, 644-649. [CrossRef] [PubMed]

119. Salvo, F.; Luppi, F.; Lucchesi, D.M.; Canovi, S.; Franchini, S.; Polese, A.; Santi, F.; Trabucco, L.; Fasano, T.; Ferrari, A.M. Serum Copeptin levels in the emergency department predict major clinical outcomes in adult trauma patients. BMC Emerg. Med. 2020, 20, 14. [CrossRef] [PubMed]

120. Nass, R.D.; Motloch, L.J.; Paar, V.; Lichtenauer, M.; Baumann, J.; Zur, B.; Hoppe, U.C.; Holdenrieder, S.; Elger, C.E.; Surges, R. Blood markers of cardiac stress after generalized convulsive seizures. Epilepsia 2019, 60, 201-210. [CrossRef]

121. Evers, K.S.; Hügli, M.; Fouzas, S.; Kasser, S.; Pohl, C.; Stoecklin, B.; Bernasconi, L.; Kuhle, J.; Wellmann, S. Serum Neurofilament Levels in Children With Febrile Seizures and in Controls. Front. Neurosci. 2020, 14, 579958. [CrossRef]

122. Wellmann, S.; Benzing, J.; Cippà, G.; Admaty, D.; Creutzfeldt, R.; Mieth, R.A.; Beinder, E.; Lapaire, O.; Morgenthaler, N.G.; Haagen, U.; et al. High copeptin concentrations in umbilical cord blood after vaginal delivery and birth acidosis. J. Clin. Endocrinol. Metab. 2010, 95, 5091-5096. [CrossRef] [PubMed]

123. Blohm, M.E.; Arndt, F.; Fröschle, G.M.; Langenbach, N.; Sandig, J.; Vettorazzi, E.; Mir, T.S.; Hecher, K.; Weil, J.; Kozlik-Feldmann, R.; et al. Cardiovascular Biomarkers in Amniotic Fluid, Umbilical Arterial Blood, Umbilical Venous Blood, and Maternal Blood at Delivery, and Their Reference Values for Full-Term, Singleton, Cesarean Deliveries. Front. Pediatr. 2019, 7, 271. [CrossRef]

124. Schlapbach, L.J.; Frey, S.; Bigler, S.; Manh-Nhi, C.; Aebi, C.; Nelle, M.; Nuoffer, J.M. Copeptin concentration in cord blood in infants with early-onset sepsis, chorioamnionitis and perinatal asphyxia. BMC Pediatr. 2011, 11, 38. [CrossRef]

125. Burkhardt, T.; Schwabe, S.; Morgenthaler, N.G.; Natalucci, G.; Zimmermann, R.; Wellmann, S. Copeptin: A marker for stress reaction in fetuses with intrauterine growth restriction. Am. J. Obstet. Gynecol. 2012, 207, 497.e1-e5. [CrossRef] [PubMed]

126. Rouatbi, H.; Zigabe, S.; Gkiougki, E.; Vranken, L.; Van Linthout, C.; Seghaye, M.C. Biomarkers of neonatal stress assessment: A prospective study. Early Hum. Dev. 2019, 137, 104826. [CrossRef]

127. Vuohelainen, T.; Ojala, R.; Virtanen, A.; Holm, P.; Tammela, O. Predictors of delayed first voiding in newborn. Acta Paediatr. 2008, 97, 904-908. [CrossRef] [PubMed]

128. Kasser, S.; Hartley, C.; Rickenbacher, H.; Klarer, N.; Depoorter, A.; Datta, A.N.; Cobo, M.M.; Goksan, S.; Hoskin, A.; Magerl, W.; et al. Birth experience in newborn infants is associated with changes in nociceptive sensitivity. Sci. Rep. 2019, 9, 4117. [CrossRef] [PubMed]

129. Hoffiz, Y.C.; Castillo-Ruiz, A.; Hall, M.A.L.; Hite, T.A.; Gray, J.M.; Cisternas, C.D.; Cortes, L.R.; Jacobs, A.J.; Forger, N.G. Birth elicits a conserved neuroendocrine response with implications for perinatal osmoregulation and neuronal cell death. Sci. Rep. 2021, 11, 2335. [CrossRef] [PubMed]

130. Urwyler, S.A.; Schuetz, P.; Sailer, C.; Christ-Crain, M. Copeptin as a stress marker prior and after a written examination-The CoEXAM study. Stress 2015, 18, 134-137. [CrossRef] 
131. Siegenthaler, J.; Walti, C.; Urwyler, S.A.; Schuetz, P.; Christ-Crain, M. Copeptin concentrations during psychological stress: The PsyCo study. Eur. J. Endocrinol. 2014, 171, 737-742. [CrossRef]

132. Spanakis, E.K.; Wand, G.S.; Ji, N.; Golden, S.H. Association of HPA axis hormones with copeptin after psychological stress differs by sex. Psychoneuroendocrinology 2016, 63, 254-261. [CrossRef]

133. Bae, Y.J.; Reinelt, J.; Netto, J.; Uhlig, M.; Willenberg, A.; Ceglarek, U.; Villringer, A.; Thiery, J.; Gaebler, M.; Kratzsch, J. Salivary cortisone, as a biomarker for psychosocial stress, is associated with state anxiety and heart rate. Psychoneuroendocrinology 2019, 101, 35-41. [CrossRef] [PubMed]

134. Goetze, J.P.; Støving, R.K. Copeptin in anorexia nervosa. Brain Behav. 2020, 10, e01551. [CrossRef] [PubMed]

135. Tirabassi, G.; Boscaro, M.; Arnaldi, G. Harmful effects of functional hypercortisolism: A working hypothesis. Endocrine 2014, 46, 370-386. [CrossRef] [PubMed] 